\title{
Calorimetric investigation of Na-K mixing and polymorphism in the alkali feldspars*
}

\author{
By D. R. WAldbal II**
}

Harvard University, Cambridge, Massachusetts

and R. A. RobIE

U. S. Geological Survey, Silver Spring, Maryland

(Received 10 October 1970)

\section{Auszug}

Im System $\mathrm{Na}\left(\mathrm{AlSi}_{3} \mathrm{O}_{8}\right)-\mathrm{K}\left(\mathrm{AlSi}_{3} \mathrm{O}_{8}\right)$ wurden die Enthalpien für die Na-KMischung, für die Al-Si-Ordnung und für das Schmelzen sowohl der Endglieder wie auch der Mischkristalle kalorimetrisch bestimmt. Dazu diente ein isoperibolisches, vakuumisoliertes Kalorimeter mit dem die Lösungswärmen in 20,1 -\% $\%$ iger Flußsäure im Bereich von $40-60^{\circ} \mathrm{C}$ gemessen wurden. Bei $49,7^{\circ} \mathrm{C}$ können die Lösungswärmen von synthetisch hergestelltem Mikroklin(Tiefalbit)Mischkristallen durch folgende Gleichung ausgedrückt werden,

$$
\bar{H}_{\mathrm{sol}}=-149,408+5,230 N_{2}-5,928 N_{2} N_{2}^{2}-8,457 N_{2} N_{1}^{2} \mathrm{kcal} / \mathrm{mol},
$$

wobei $N_{1}$ und $N_{2}$ den Molanteilen von $\mathrm{NaAlSi}_{3} \mathrm{O}_{8}$ bzw. $\mathrm{KAlSi}_{3} \mathrm{O}_{8}$ entsprechen. Die Fehlergrenze bei dieser aus 39 Einzelmessungen ermittelten Least-squaresFormel beträgt $\pm 0,032 \mathrm{kcal} / \mathrm{mol}$.

Die mit Least-squares-Verfeinerung aus den Röntgendaten erhaltenen Gitterkonstanten zeigen, daß die Überschußvolumina der Na-K-Mischung in diesen Mischkristallen über den ganzen Zusammensetzungsbereich positiv sind. Die Kombination der kalorimetrischen und der kristallographischen Daten führt zu folgendem Ausdruck für die Änderung der molaren Mischungsenthalpie mit dem Druck :

$$
\bar{H}_{\mathrm{ex}}=(5928+0,110 P) N_{1} N_{2}^{2}+(8457+0,110 P) N_{2} N_{1}^{2} \mathrm{cal} / \mathrm{mol}
$$

* Published under the auspices of the Committee on Experimental Geology and Geophysics, Harvard University. Publication authorized by the Director, U.S. Geological Survey. Preliminary results presented to The Calorimetry Conference in Boulder, Colorado, June, 1966; and the Geological Society of America (NE Sect.) in Boston, March, 1967.

** Present address: Department of Geological and Geophysical Sciences, Princeton University, Princeton, New Jersey 08540. 
Das Vorzeichen und die Größenordnung von $\bar{H}_{\text {ex }}$, aus kalorimetrischen Messungen ermittelt, stimmt sehr gut mit dem aus einer Margules-Formel dritter Ordnung berechneten $\bar{H}_{\text {ex }}$ überein, entsprechend der Formulierung von Hochtemperatur-Zweiphasen-Gleichgewichtsdaten für den kritischen Bereich.

\begin{abstract}
Heat of solution measurements of the enthalpies of $\mathrm{Na}-\mathrm{K}$ mixing, Al-Si ordering, and fusion for crystalline solutions and end-member phases in the system $\mathrm{Na}\left(\mathrm{AlSi}_{3} \mathrm{O}_{8}\right)-\mathrm{K}\left(\mathrm{AlSi}_{3} \mathrm{O}_{8}\right)$ were obtained with a vacuum-jacketed, isoperibolic calorimeter using 20.1 percent hydrofluoric acid at temperatures ranging from 40 to $60^{\circ} \mathrm{C}$. Heat of solution data for artificially prepared microcline (-low-albite) crystalline solutions at $49.7^{\circ} \mathrm{C}$ are represented by
\end{abstract}

$$
\bar{H}_{\text {Bol }}=-149.408+5.230 N_{2}-5.928 N_{1} N_{2}^{2}-8.457 N_{2} N_{1}^{2} \mathrm{kcal} / \mathrm{mole}
$$

based on 39 measurements of 14 different bulk compositions, where $N_{1}$ and $N_{2}$ denote the mole fractions of $\mathrm{NaAlSi}_{3} \mathrm{O}_{8}$ and $\mathrm{KAlSi}_{3} \mathrm{O}_{8}$ respectively. The thermochemical uncertainty of the above least-squares formulation is $\pm 0.032 \mathrm{kcal} /$ mole.

Unit-cell parameters determined by least-squares refinement of diffraction data indicate that the excess volumes of $\mathrm{Na}-\mathrm{K}$ mixing of these microcline solutions are positive over the entire composition range. Combining the calorimetric and crystallographic data leads to the following expression for the variation of molar enthalpy of mixing with pressure:

$$
\bar{H}_{\mathrm{ex}}=(5928+0.110 P) N_{1} N_{2}^{2}+(8457+0.110 P) N_{2} N_{1}^{2} \text { cal } / \mathrm{mole} .
$$

The sign and magnitude of $H_{\mathrm{ex}}$ determined by calorimetry agree closely with $H_{\text {ex }}$ calculated from a third-order Margules formulation of high-temperature two-phase equilibrium data in the critical region.

\title{
Introduction
}

The thermodynamic properties and phase relations of alkali feldspars are similar in many respects to those of other $\mathrm{Na}-\mathrm{K}$ crystalline solutions having very different crystal structures (THомpson and Waldbaum, 1969a, $1969 \mathrm{~b}$; Eugster et al., 1972). The $\mathrm{AlSi}_{3} \mathrm{O}_{8}$ framework of the feldspars, however, is more complex than the frameworks of other $\mathrm{Na}-\mathrm{K}$ crystalline solutions such as the micas and chlorides. There are at least two and possibly four non-equivalent tetrahedral cation sites in the alkali-feldspar structure (TAYLOR, 1934; LAVES and HAFNer, 1962 ; Thompson, 1969, Fig. 4 and references cited therein). With four distinct tetrahedral sites, one must specify three sets of homogeneous equilibrium parameters in addition to $\mathrm{Na}-\mathrm{K}$ mixing parameters in order to completely describe the equilibrium properties of an alkali feldspar (HAFNER and LAves, 1957; Barth, 1965). 
In many natural alkali feldspars, microclines and low albites, the ordering parameters $Y$ and $Z$ defined by Thompson $(1969,1970)$ are very nearly +1 and the $X$ parameter is close to zero, where:

$$
\begin{aligned}
& X \equiv N_{\mathrm{Al}(\mathrm{T} 20)}-N_{\mathrm{Al}(\mathrm{T} 2 m)} \\
& Y \equiv N_{\mathrm{Al}(\mathrm{T} 10)}-N_{\mathrm{Al}(\mathrm{T} 1 m)}-N_{\mathrm{Al}(\mathrm{T} 20)}-N_{\mathrm{Al}(\mathrm{T} 2 m)}
\end{aligned}
$$

and $N_{\mathrm{Al}}$ is the average atomic fraction $\mathrm{Al} /(\mathrm{Al}+\mathrm{Si})$ in the tetrahedral sites $\mathrm{T}_{1}(0), \mathrm{T}_{1}(m), \mathrm{T}_{2}(0)$, and $\mathrm{T}_{2}(m)$.

Structure data for synthetic sanidines and high albites, which are representative of the most highly disordered feldspars known, indicate that all three $X, Y$, and $Z$ parameters are near zero (Thompsos, 1969 , Table 1, Figs. 6 and 7). Anti-ordered Al-Si distributions (negative $Z$ ) are theoretically possible structures, but have not as yet been discovered among natural or synthetic feldspars.

The effects of temperature, pressure, and composition on equilibrium values of $X, Y$, and $Z$ are known only qualitatively from experimental studies such as those of TUTTLE and Bowen (1950), DonNaY and Donsay (1952), Goldsmith and Laves (1954), MacKenzie (1957), Orvinle (1963, 1967), Lindsley (1966), Luth and Tuttle (1966), Parsons (1968), Martin (1969), and Morse (1970), mainly because direct structure determinations have not been carried out on the synthetic feldspars (one exception being the high albite studied by Wirluams and Mraaw, 1964). The difficulties encountered in interpreting such data are well-illustrated in discussions by Laves (1960) and MacKenzie and SMTtH (1961). It is unlikely that homogeneous and heterogeneous phase relations in natural or synthetic feldspars can be interpreted accurately, or at least unambiguously, without the additional crystallographic, phase equilibrium, and calorimetric data needed to formulate a complete thermodynamic equation of state for the alkali feldspars.

In the present investigation we have obtained calorimetric and crystallographic data on the enthalpies and volumes of Al-Si disordering and the enthalpies of fusion of the sodium and potassium endmembers, and data on the enthalpies and volumes of $\mathrm{Na}-\mathrm{K}$ mixing for highly ordered low-albite-microcline crystalline solutions. For practical experimental reasons, we initially selected alkali feldspars with highly-ordered $(X \cong 0, Y \cong Z \cong 1)$ and highly-disordered $(X \cong Y \cong Z \cong 0)$ frameworks. Well-defined, highly-ordered feldspars are abundant in nature and highly-disordered ones can be re- 
producibly prepared in large quantities. As in previous thermodynamic and synthesis studies, the tetrahedral-site populations of these feldspars were not determined from single-crystal structure data. Hence, the terms "highly-ordered" and "highly-disordered" are qualitative and based only on a comparison of unit-cell parameters with those of previously determined feldspar structures.

Hydrofluoric acid solution calorimetry was used to obtain the enthalpy data. KRACEK and NeUvonen (1952) also used this method successfully to obtain similar data on natural feldspars; however, the samples used by KRACEK and Neuvonen contained varying amounts of other feldspar components, and the descriptions indicate substantial differences in Al-Si distributions and homogenity among the samples (detailed x-ray crystallographic data were not obtained). Recent development of a vacuum-jacketed solution calorimeter for use with hydrofluoric acid (RoBIE, 1965) and improved methods for purifying and controlling the synthesis of alkali feldspars (WYART and SABATIER, 1956; HAFNer and LAves, 1957; Orville, 1967) suggested that data of considerably higher precision could be obtained on more accurately characterized samples.

\section{Synthesis, composition, and unit-cell data}

The kinetics of both Na-K phase separation and Al-Si ordering in feldspars are slow enough to permit phases that may be thermodynamically metastable at room temperature and pressure to be quenched and preserved indefinitely (for all practical purposes) without the special precautions usually needed for alloys and alkali halides. It is therefore possible to obtain calorimetric data on the $\mathrm{Na}-\mathrm{K}$ mixing properties of alkali feldspars for a framework of given constant $\mathrm{Al}-\mathrm{Si}$ distribution for all bulk compositions, even though that distribution may be metastable with respect to some other distribution for the conditions of synthesis or the conditions of the calorimetric experiments. It is emphasized that the Al-Si distributions in the feldspars described below were not necessarily the most stable internal equilibrium values at either the annealing temperatures or the conditions under which the calorimetric and crystallographic data were obtained.

\section{(a) End-member feldspars}

Calorimetric samples of the end-member polymorphs were obtained from a single starting material-a natural low albite from the Rutherford Mine in Amelia County, Virginia (Sinkankas, 1968). "Amelia 
albite" (var. cleavelandite) is well known for its high chemical and phase purity, and it was also used in calorimetric studies by KrACEK and Neuvonen (1952) and Holm and Kleppa (1968). The present material was selected from a group of water-clear cleavage fragments about $1 \mathrm{~cm}$ across. All cloudy white crystals or fragments having a blue iridescence (peristerite) were excluded. Unit-cell parameters of this material are given in Table 1.

Quantitative emission-spectrographic analysis indicates that this albite has a low strontium content compared with other feldspars (HEIER, 1962), but that other minor elements are present in the ranges found in most other albites. The analytical data are given in Tables 2 and 3. The gravimetric analysis yielded a $\mathrm{CaO}$ content of 0.02 weight percent. All materials were crushed and ground in a 4-cm-diameter tungsten-carbide ball mill, and sized with Nylon sieves. No contamination by tungsten carbide was detected in any of the spectrographic analyses.

High albite (sample 6406-Cl) was prepared by heating some of the low albite in a platinum crucible in a silicon-carbide furnace for 668 hours at $1060^{\circ} \mathrm{C}$. This temperature was probably high enough for the albite to acquire dimensional monoclinic symmetry (GRUNDY et al., 1967), and the material is thus likely to have a monoclinic Al-Si distribution despite its triclinic symmetry at room temperature. The monoclinic Al-Si distribution appears to be confirmed by the fact that a monoclinic sanidine was produced when the high albite was exchanged in fused $\mathrm{KCl}$ (see below).

Low albite (6454) with a lower $\mathrm{K}$ content was prepared by heating the original Amelia albite in fused $\mathrm{NaCl}$ at $900^{\circ} \mathrm{C}$. The slight decrease in the $a$ cell dimension (Table 1 ) is consistent with a loss of $K$ due to ion exchange. The unit-cell parameters of the albites given in Table 1 are also compared in Table 2 of KASTNER and WALDBAUM (1968) with previous determinations on high and low albites prepared in a similar way and by hydrothermal synthesis (see also OrVILLE, 1967; WrIGHT and STEWART, 1968), and with albites whose Al-Si distributions have been determined by complete structure refinements. This comparison indicates that the fused-salt ion-exchange treatment had no detectable effect on the original Al-Si distribution.

Potassium feldspars having corresponding $\mathrm{Al}-\mathrm{Si}$ distributions were prepared by converting portions of the above-described albite polymorphs to microcline (6452) and sanidine (6457), respectively, by ion-exchange in fused $\mathrm{KCl}$ for 24 hours at $900^{\circ} \mathrm{C}$ (platinum crucible). 
Table 1. Cnit-cell parameters of end-member alkali feldspars

Least-squares standard errors as defined by BurnhaM (1962) are given below each parameter. Reflnements numbered in italics were obtained by D. B. STEWART (1965, written comm.) with fluorite as an internal standard; refinement MK from KASTNER (1969), silicon standard; LQS from LUTH and QUEROL-SUÑ $\varepsilon^{\prime}$ (1970), spinel standard

\begin{tabular}{|c|c|c|c|c|c|c|c|c|c|}
\hline $\begin{array}{l}\text { Sample/ } \\
\text { Refineme } \\
\text { No.lines }\end{array}$ & lent No.l & Synthesis history" & $\stackrel{a}{a}(\AA)$ & $\begin{array}{c}b \\
(\AA)\end{array}$ & $\begin{array}{c}c \\
(\AA)\end{array}$ & $\alpha$ & $\beta$ & $\gamma$ & $\begin{array}{c}\nabla \\
(\mathrm{cal} / \mathrm{bar})\end{array}$ \\
\hline 6306 & R292 30 & $\begin{array}{l}\text { Low albite, Nc } \\
\text { (Amelia, Virginia) }\end{array}$ & $\begin{array}{r}8.1414 \\
\pm .0016\end{array}$ & $\begin{array}{r}12.7830 \\
.0020\end{array}$ & $\begin{array}{r}7.1571 \\
.0011\end{array}$ & $\begin{array}{c}94.233^{\circ} \\
.016\end{array}$ & $\begin{array}{c}116.592^{\circ} \\
.012\end{array}$ & $\begin{array}{r}87.680^{\circ} \\
.015\end{array}$ & $\begin{array}{r}2.3907 \\
.0009\end{array}$ \\
\hline 6454 & R191 19 & $\begin{array}{l}\text { Low albite } \\
\text { EDNc: } 910^{\circ} \mathrm{C}, 24 \mathrm{hr}, \mathrm{NaCl}\end{array}$ & $\begin{array}{r}8.1359 \\
.0031\end{array}$ & $\begin{array}{r}12.7844 \\
.0049\end{array}$ & $\begin{array}{r}7.1573 \\
.0014\end{array}$ & $\begin{array}{r}94.245 \\
.022\end{array}$ & $\begin{array}{r}116.568 \\
.014\end{array}$ & $\begin{array}{r}87.689 \\
.027\end{array}$ & $\begin{array}{r}2.3897 \\
.0014\end{array}$ \\
\hline $6001 \mathrm{H}$ & R315 51 & Low albite, Nch & $\begin{array}{r}8.1425 \\
.0010\end{array}$ & $\begin{array}{r}12.7912 \\
.0022\end{array}$ & $\begin{array}{r}7.1617 \\
.0011\end{array}$ & $\begin{array}{r}94.221 \\
.019\end{array}$ & $\begin{array}{r}116.639 \\
.013\end{array}$ & $\begin{array}{r}87.749 \\
.018\end{array}$ & $\begin{array}{r}2.3931 \\
.0010\end{array}$ \\
\hline 6406 A 1 & R298 27 & $\begin{array}{l}\text { Albite } \\
\text { ANe: } 1060,173\end{array}$ & $\begin{array}{r}8.1529 \\
.0051\end{array}$ & $\begin{array}{r}12.8043 \\
.0038\end{array}$ & $\begin{array}{r}7.1423 \\
.0035\end{array}$ & $\begin{array}{r}94.067 \\
.039\end{array}$ & $\begin{array}{r}116.546 \\
.032\end{array}$ & $\begin{array}{r}88.371 \\
.041\end{array}$ & $\begin{array}{r}2.3945 \\
.0027\end{array}$ \\
\hline $6406 \mathrm{~B} 1$ & R211 34 & $\begin{array}{l}\text { High albite } \\
\text { ANc: } 1060,508\end{array}$ & $\begin{array}{r}8.1574 \\
.0021\end{array}$ & $\begin{array}{r}12.8704 \\
.0015\end{array}$ & $\begin{array}{r}7.1132 \\
.0012\end{array}$ & $\begin{array}{r}93.541 \\
.017\end{array}$ & $\begin{array}{r}116.461 \\
.012\end{array}$ & $\begin{array}{r}90.121 \\
.020\end{array}$ & $\begin{array}{r}2.3895 \\
.0010\end{array}$ \\
\hline 6413 & R 26023 & $\begin{array}{l}\text { High albite } \\
\operatorname{EDED}(6409): 915,24, \mathrm{NaCl}\end{array}$ & $\begin{array}{r}8.1559 \\
.0024\end{array}$ & $\begin{array}{r}12.8645 \\
.0020\end{array}$ & $\begin{array}{r}7.1148 \\
.0018\end{array}$ & $\begin{array}{r}93.573 \\
.021\end{array}$ & $\begin{array}{r}116.478 \\
.016\end{array}$ & $\begin{array}{r}90.182 \\
.024\end{array}$ & $\begin{array}{r}2.3987 \\
.0014\end{array}$ \\
\hline $6406 \mathrm{Cl}$ & R247 34 & $\begin{array}{l}\text { High albite } \\
\text { ANc: } 1060,668\end{array}$ & $\begin{array}{r}8.1627 \\
.0020\end{array}$ & $\begin{array}{r}12.8729 \\
.0016\end{array}$ & $\begin{array}{r}7.1141 \\
.0010\end{array}$ & $\begin{array}{r}93.545 \\
.019\end{array}$ & $\begin{array}{r}116.460 \\
.011\end{array}$ & $\begin{array}{r}90.131 \\
.023\end{array}$ & $\begin{array}{r}2.4026 \\
.0009\end{array}$ \\
\hline $6609 \mathrm{H}$ & R331 43 & $\begin{array}{l}\text { High albite } \\
\text { ANch: } 1045,840\end{array}$ & $\begin{array}{r}8.1586 \\
.0017\end{array}$ & $\begin{array}{r}12.8738 \\
.0009\end{array}$ & $\begin{array}{r}7.1126 \\
.0010\end{array}$ & $\begin{array}{r}93.462 \\
.010\end{array}$ & $\begin{array}{r}116.431 \\
.009\end{array}$ & $\begin{array}{r}90.240 \\
.013\end{array}$ & $\begin{array}{r}2.4018 \\
.0008\end{array}$ \\
\hline 6301 & R14426 & $\begin{array}{l}\text { Microcline } \\
\text { EDNc: } 860,24, \mathrm{KCl}\end{array}$ & $\begin{array}{r}8.5840 \\
.0017\end{array}$ & $\begin{array}{r}12.9714 \\
.0020\end{array}$ & $\begin{array}{r}7.2234 \\
.0010\end{array}$ & $\begin{array}{r}90.653 \\
.014\end{array}$ & $\begin{array}{r}115.919 \\
.012\end{array}$ & $\begin{array}{r}87.619 \\
.016\end{array}$ & $\begin{array}{r}2.6012 \\
.0009\end{array}$ \\
\hline 6452 & R300 52 & $\begin{array}{l}\text { Microcline } \\
\text { EDNc: } 910,25, \mathrm{KCl}\end{array}$ & $\begin{array}{r}8.5836 \\
.0016\end{array}$ & $\begin{array}{r}12.9723 \\
.0015\end{array}$ & $\begin{array}{r}7.2238 \\
.0009\end{array}$ & $\begin{array}{r}90.619 \\
.013\end{array}$ & $\begin{array}{r}115.924 \\
.010\end{array}$ & $\begin{array}{r}87.650 \\
.012\end{array}$ & $\begin{array}{r}2.6014 \\
.0009\end{array}$ \\
\hline 6452 & R 73928 & $\begin{array}{l}\text { Microcline } \\
\text { (see above) }\end{array}$ & $\begin{array}{r}8.5801 \\
.0021\end{array}$ & $\begin{array}{r}12.9646 \\
.0011\end{array}$ & $\begin{array}{r}7.2218 \\
.0026\end{array}$ & $\begin{array}{r}90.611 \\
.014\end{array}$ & $\begin{array}{r}115.938 \\
.012\end{array}$ & $\begin{array}{r}87.642 \\
.014\end{array}$ & $\begin{array}{r}2.5977 \\
.0010\end{array}$ \\
\hline 6452 & LQS 62 & $\begin{array}{l}\text { Microcline } \\
\text { (see above) }\end{array}$ & $\begin{array}{r}8.5830 \\
.0010\end{array}$ & $\begin{array}{r}12.9647 \\
.0011\end{array}$ & $\begin{array}{r}7.2226 \\
.0009\end{array}$ & $\begin{array}{r}90.617 \\
.010\end{array}$ & $\begin{array}{r}115.920 \\
.010\end{array}$ & $\begin{array}{r}87.658 \\
.010\end{array}$ & $\begin{array}{r}2.5994 \\
.0003\end{array}$ \\
\hline 6804 & MK & $\begin{array}{l}\text { Microcline } \\
\text { EDNe: } 816,29, \mathrm{KCl}\end{array}$ & $\begin{array}{r}8.5764 \\
.0026\end{array}$ & $\begin{array}{r}12.9621 \\
.0017\end{array}$ & $\begin{array}{r}7.2221 \\
.0019\end{array}$ & $\begin{array}{r}90.612 \\
.023\end{array}$ & $\begin{array}{r}115.918 \\
.015\end{array}$ & $\begin{array}{r}87.686 \\
.020\end{array}$ & $\begin{array}{r}2.5067 \\
.0015\end{array}$ \\
\hline $6442 \mathrm{KX}$ & R704 19 & $\begin{array}{l}\text { Microcline } \\
\text { EDAMED (6442): (?), KCl }\end{array}$ & $\begin{array}{r}8.6018 \\
.0036\end{array}$ & $\begin{array}{r}12.9650 \\
.0027\end{array}$ & $\begin{array}{r}7.2206 \\
.0011\end{array}$ & $\begin{array}{r}90.522 \\
.023\end{array}$ & $\begin{array}{r}115.876 \\
.018\end{array}$ & $\begin{array}{r}87.852 \\
.027\end{array}$ & $\begin{array}{r}2.6057 \\
.0010\end{array}$ \\
\hline 6407 & R232 28 & $\begin{array}{l}\text { Microcline } \\
\operatorname{ED}(6406 \mathrm{~A} 1): 882,19, \mathrm{KCl}\end{array}$ & $\begin{array}{r}8.5939 \\
.0034\end{array}$ & $\begin{array}{r}12.9809 \\
.0025\end{array}$ & $\begin{array}{r}7.2040 \\
.0021\end{array}$ & $\begin{array}{r}90.315 \\
.028\end{array}$ & $\begin{array}{r}115.913 \\
.018\end{array}$ & $\begin{array}{r}88.428 \\
.032\end{array}$ & $\begin{array}{r}2.6005 \\
.0018\end{array}$ \\
\hline 6409 & R256 44 & $\begin{array}{l}\text { Sanidine } \\
\operatorname{ED}(6406 \mathrm{~B} \mathrm{1}): 881,22, \mathrm{KCl}\end{array}$ & $\begin{array}{r}8.6061 \\
.0016\end{array}$ & $\begin{array}{r}19.0283 \\
.0014\end{array}$ & $\begin{array}{r}7.1828 \\
.0014\end{array}$ & 90.0 & $\begin{array}{r}115.999 \\
.012\end{array}$ & 90.0 & $\begin{array}{r}2.6052 \\
.0011\end{array}$ \\
\hline 6457 & R254 64 & $\begin{array}{l}\text { Sanidine } \\
\operatorname{ED}(\theta 406 \mathrm{C} 1): 910,24, \mathrm{KCl}\end{array}$ & $\begin{array}{r}8.6079 \\
.0012\end{array}$ & $\begin{array}{r}13.0354 \\
.0011\end{array}$ & $\begin{array}{r}7.1817 \\
.0009\end{array}$ & 90.0 & $\begin{array}{r}116.012 \\
.008\end{array}$ & 90.0 & $\begin{array}{r}2.6065 \\
.0007\end{array}$ \\
\hline
\end{tabular}

- Symbols denoting synthesis history are as follows: $A$, heated (annealed) in air; $E D$, fused-salt-exchange derivatlve; $F$, fused in alr; $M$, mechanical mixture; $N c$, (natural) Amelia albite (this study); $N$ ch, Amelia albite (HowK and KLEPPA, 1968); $N z$, (natural) Amelia microcline. Numbers in parentheses give sample number of starting material. Data following colon are: temperature $\left({ }^{\circ} \mathrm{C}\right.$ ), time (hours), and reagent composition. Additional detalls In Table 2-5 of WaLDBAUK (1966). 
Table 2. Spectrographic analyses of minor elements Symbols are: *, natural starting material; SQ, semiquantitative; $Q$, quantitative; nd, looked for but not detected; - , not looked for. The following elements were also looked for but not detected: $\mathrm{Fe}, \mathrm{Mg}, \mathrm{Ti}, \mathrm{P}, \mathrm{Mn}, \mathrm{Ag}, \mathrm{As}, \mathrm{Au}, \mathrm{Bi}, \mathrm{Cd}, \mathrm{Ce}, \mathrm{Co}$, $\mathrm{Cr}, \mathrm{Ge}, \mathrm{Hf}, \mathrm{Hg}$, In, La, Li, Mo, Nb, Ni, Pd, Pt, Re, Sb, Sc, Sn, Ta, Te, Th, U, V, $\mathrm{W}, \mathrm{Y}, \mathrm{Yb}, \mathrm{Zn}$, and $\mathrm{Zr}$. Semiquantitative results are reported in weight- $\%$ to the nearest number in the series $1,0.7,0.5,0.3,0.15,0.1$, etc., which represent approximate midpoints of group data on a geometric scale. The assigned group will include the quantitative value $30 \%$ of the time (analysts, J. L. HARRIs and J. D. Fletcher, U. S. Geological Survey)

\begin{tabular}{l|l|l|l|l|l|l|l|l|l|l}
\hline Sample** & & $\mathrm{T} l$ & $\mathrm{Cu}$ & $\mathrm{Be}$ & $\mathrm{Ca}$ & $\mathrm{Sr}$ & $\mathrm{Ba}$ & $\mathrm{Pb}$ & $\mathrm{B}$ & $\mathrm{Ga}$ \\
\hline
\end{tabular}

Amelia albite and ion-exchange derivatives:

\begin{tabular}{l|r|l|l|l|l|l|l|l|l|l}
$6306^{*}$ & $\mathrm{SQ}$ & $\mathrm{nd}$ & .0001 & .0007 & .07 & .0007 & .0003 & .01 & .003 & .007 \\
$6306^{*}$ & $\mathrm{Q}$ & - & - & - & .019 & .0022 & $<.002$ & .017 & $<.002$ & .005 \\
$6314^{*}$ & $\mathrm{SQ}$ & nd & .0020 & .0007 & .07 & .001 & nd & .01 & .003 & .007 \\
6454 & $\mathrm{SQ}$ & nd & .0003 & .0007 & .05 & .001 & .0003 & .01 & .003 & .007 \\
6452 & $\mathrm{SQ}$ & nd & .0007 & .0005 & .05 & .001 & .0003 & .007 & .003 & .005 \\
6457 & $\mathrm{Q}$ & - & - & - & .0019 & - & - & - & - & -
\end{tabular}

Amelia microcline and ion-exchange derivatives:

\begin{tabular}{l|r|l|l|l|l|l|l|l|l|l}
$6308 *$ & $\mathrm{SQ}$ & $\mathrm{nd}$ & .0003 & .0005 & .007 & .003 & .002 & .07 & .003 & .003 \\
$6308 *$ & $\mathrm{Q}$ & - & - & - & .002 & .0023 & $<.002$ & .14 & $<.002$ & .0023 \\
6427 & $\mathrm{SQ}$ & .007 & .0015 & .0005 & .0005 & .0015 & $\mathrm{nd}$ & .05 & .003 & .002 \\
6438 & $\mathrm{SQ}$ & .007 & .0002 & .0003 & .001 & .0015 & .001 & .07 & .003 & .003 \\
$6453 \mathrm{~A}$ & $\mathrm{SQ}$ & nd & .0005 & .0005 & .007 & .0015 & .0015 & .05 & .003 & .003 \\
6444 & $\mathrm{SQ}$ & nd & .0007 & .0005 & .005 & .0015 & .0015 & .07 & .003 & .005 \\
6443 & $\mathrm{SQ}$ & nd & .0007 & .0003 & .003 & .0015 & .001 & .05 & .003 & .003 \\
$\mathbf{6 4 4 0}$ & $\mathrm{SQ}$ & nd & .0007 & .0005 & .002 & .0015 & .0015 & .07 & .003 & .005 \\
6426 & $\mathrm{SQ}$ & .001 & .001 & .0007 & .0015 & .002 & $\mathrm{nd}$ & .05 & .003 & .003 \\
6429 & $\mathrm{SQ}$ & nd & .0003 & .0007 & .0015 & .0015 & .0015 & .05 & .003 & .005
\end{tabular}

** Synthesis history given in Tables 1 and 3.

Here again no significant change in Al-Si distribution during ion exchange is indicated. No petrographic, diffraction, or electron microprobe evidence was found to suggest that phases other than a single homogeneous alkali feldspar resulted from fused-salt ion exchange. Partial chemical analyses of the ion-exchanged derivatives are given in Tables 2 and 3.

The physical properties of these feldspars should, in a strict sense, only be compared with synthetic feldspars annealed by simple dry heating, or those heated in a fused salt, or crystallized in a peralkaline hydrothermal fluid, inasmuch as feldspars crystallized in pure water 
Table 3. Partial chemical analyses for major elements (wt- $\%$ )

Methods of analysis: $\mathrm{Na}_{2} \mathrm{O}, \mathrm{K}_{2} \mathrm{O}$-I, and $\mathrm{Rb}_{2} \mathrm{O}$, flame photometry (J. J. WARR, JR., U.S.G.S., and H.W. KreUGer, analysts); $\mathrm{K}_{2} \mathrm{O}$-II, $\mathrm{x}$-ray fluorescence (RobenA Brown and H.J.Rose, U.S.G.S.); italics denote atomic absorption analyses (J. Ito, Harvard); $\mathrm{SiO}_{2}$ and $\mathrm{Al}_{2} \mathrm{O}_{3}$, gravimetric (J. J. FAHEY, U.S.G.S.). Each value represents replicate ( 2 to 6 ) analyses on separate splits. Analyses for $\mathrm{Cs}_{2} \mathrm{O}$ and $\mathrm{Li}_{2} \mathrm{O}$ (flame) indicated less than 0.05 and 0.005 wt- $\%$ respectively for all samples. Values in parentheses are estimates based on electron microprobe analyses

\begin{tabular}{|c|c|c|c|c|c|c|c|}
\hline Sample & Synthesis history* & $\mathrm{Na}_{2} \mathrm{O}$ & $\mathrm{K}_{2} \mathrm{O}-\mathrm{I}$ & $\mathrm{K}_{2} \mathrm{O} \cdot \mathrm{II}$ & $\mathrm{Rb}_{2} \mathrm{O}$ & $\mathrm{SiO}_{2}$ & $\mathrm{Al}_{2} \mathrm{O}_{3}$ \\
\hline 6308 & Amelia microcline $(\mathrm{Nz})$ & $\begin{array}{l}1.74 \\
1.73 \\
1.70 \\
1.83\end{array}$ & $\begin{array}{l}13.56 \\
13.6 \\
13.52 \\
13.33\end{array}$ & 13.7 & $\begin{array}{l}0.83 \\
0.83\end{array}$ & 65.34 & 18.74 \\
\hline 6446 & $\mathrm{EDNz}: 925^{\circ} \mathrm{C}, 145 \mathrm{hr}, \mathrm{KCl}$ & $<0.10$ & 16.58 & 16.7 & 0.77 & - & - \\
\hline 6438 & EDNz : $910,24, \mathrm{KCl}$ & $<0.10$ & 16.21 & 16.3 & 0.81 & - & - \\
\hline 6427 & EDNz : 910, 24, $\mathrm{KCl}$ & $<0.10$ & 15.91 & 16.1 & 0.60 & - & - \\
\hline 6439 & $\operatorname{AMED}(6429+6436): 925,145$ & 1.17 & 14.48 & 14.6 & 0.57 & 63.36 & 18.86 \\
\hline 6442 & $\operatorname{AMED}(6426+6436): 925,148$ & 2.20 & 12.98 & 13.3 & 0.70 & 65.10 & 19.08 \\
\hline 6449 & $\operatorname{AMED}(6440+6438): 945,169$ & 3.73 & 11.55 & 11.5 & 0.48 & - & - \\
\hline 6434 & $\operatorname{AMED}(6426+6427): 925,144$ & 4.23 & 10.50 & 10.4 & 0.55 & 66.00 & 18.98 \\
\hline $6453 \mathrm{~A}$ & $\operatorname{MED}(6437+6445)$ & - & - & 8.70 & $(0.20)$ & - & - \\
\hline $6453 \mathrm{~F}$ & $\operatorname{AMED}(6453 \mathrm{~A}): 940,363$ & - & - & 8.80 & $(0.20)$ & - & - \\
\hline 6441 & $\operatorname{AMED}(6429+6436): 926,152$ & $\begin{array}{l}5.82 \\
5.90\end{array}$ & $\begin{array}{l}8.15 \\
8.16\end{array}$ & 8.25 & $\begin{array}{l}0.50 \\
0.64\end{array}$ & 66.24 & 19.62 \\
\hline 6448 & $\operatorname{AMED}(6440+6438): 945,169$ & 6.60 & 6.61 & 6.70 & 0.24 & - & - \\
\hline 6447 & $\operatorname{AMED}(6440+6436): 935,146$ & 8.08 & 5.31 & 5.10 & 0.46 & 67.00 & 19.62 \\
\hline 6451 & $\begin{array}{l}\operatorname{AMED}(6443,6444+6438): \\
\quad 945,159\end{array}$ & 8.78 & $\mathbf{3 . 4 8}$ & 3.55 & 0.38 & - & - \\
\hline 6450 & $\operatorname{AMED}(6443+6438): 935,154$ & 10.64 & 1.95 & 2.05 & 0.34 & 67.44 & 19.88 \\
\hline 6426 & $\mathrm{EDNz}: 910,24, \mathrm{NaCl}$ & - & - & 0.26 & $(0.15)$ & - & - \\
\hline 6440 & $\mathrm{EDNz}: 915,48, \mathrm{NaCl}$ & - & - & 0.20 & $(0.15)$ & - & - \\
\hline 6443 & $\mathrm{EDNz}: 907,25, \mathrm{NaCl}$ & - & - & 0.17 & $(0.20)$ & - & - \\
\hline 6444 & $\mathrm{EDNz}: 910,26, \mathrm{NaCl}$ & 11.33 & 0.22 & 0.18 & 0.15 & - & - \\
\hline 6429 & $\operatorname{EDED}(6426): 905,18, \mathrm{NaCl}$ & - & - & 0.02 & $(0.02)$ & - & 一 \\
\hline 6306 & Amel & - & - & 0.16 & - & 68.68 & 20.26 \\
\hline 6452 & EDNc: $910,25, \mathrm{KCl}$ & 0.10 & 16.80 & 16.8 & $<0.05$ & 64.54 & 19.06 \\
\hline 6460 & EDFNe : $910,24, \mathrm{KCl}$ & $\begin{array}{l}0.36 \\
0.43\end{array}$ & $\begin{array}{l}15.34 \\
15.55\end{array}$ & 15.1 & $<0.05$ & 64.10 & 18.68 \\
\hline 6461 & EDFNc: $909,23, \mathrm{NaCl}$ & $\begin{array}{l}11.80 \\
11.78\end{array}$ & $\begin{array}{l}0.07 \\
0.03\end{array}$ & - & $<0.05$ & - & - \\
\hline
\end{tabular}

* See note in Table 1. 
may contain significant amounts of hydronium in the alkali site (Thompson and Waldbaum, 1969a, p. 826-828). Electrolytic determinations of the water content of Amelia albite exchanged in fused $\mathrm{NaCl}$ and $\mathrm{KCl}$ gave $0.0034 \pm 0.0008$ and $0.0009 \pm 0.0004$ weight percent $\mathrm{H}_{2} \mathrm{O}$, respectively, between 200 and $1000^{\circ} \mathrm{C}$ (KASTNER, 1969, p. 172).

Glasses of the end-member compositions were prepared by fusing crystal fragments of the natural albite at $1325^{\circ} \mathrm{C}(6411)$ and by exchanging the resulting $\mathrm{Na}$ glass in fused $\mathrm{KCl}(6460)$. Partial analyses of these glasses are given in Table 3, and their preparation and properties are discussed further by WALDBAUM (1969).

(b) Extent of disorder in high albite and sanidine

The $b$ and $c$ cell parameters of Amelia albite and its derivatives (Table 1) are compared in Fig. 1 with the cell parameters of alkali feldspars whose Al-Si distributions are known from structure-refinement data. For the monoclinic $K$ feldspars 6409 and 6457 , the ordering parameter $Z$ is estimated to be 0.17 and $0.14( \pm 0.02)$, respectively, from the tentative empirical relation given by Hovis et al. (1970):

$$
Z=-16.823+8.620(c-0.400 b)
$$

where the uncertainty is based on those of the cell parameters and not on the uncertainties in the site populations used to derive the equation.

It appears from Fig. 1 (and bearing in mind the uncertainties in the cell parameters) that 6409 and 6457 are not as disordered as the preferred " high sanidine" of STEWART and RIBBE (1969) which yields a value of $Z$ equal to 0.11 from the above relation. Subsequent annealing of sample 6457 at $1052 \pm 10^{\circ} \mathrm{C}$ for 448 hours showed that apparent further disordering was possible. The $b$ and $c$ parameters of this "sanidinized sanidine" $(7025 \mathrm{E})$ are $13.0317 \pm 0.0014 \AA$ and 7.1705 $\pm 0.0013 \AA$, respectively, with $Z$ estimated to be $0.05 \pm 0.02$. The calorimetric data for 6457 should not, therefore, be considered as applying to "highest" sanidine (whatever value of $Z$ that may be).

Microcline 6452 has also been annealed at $1052^{\circ} \mathrm{C}$ for successive periods of time. In the first stage of 707 hours $(7026 \mathrm{~A})$ the $x$-ray pattern indicated that the material was a mixture of monoclinic and triclinic crystals. The second stage of annealing lasted an additional 240 hours $(7026 \mathrm{~B})$ and the $x$-ray data still showed signs of heterogeneity in the powder. After an additional 530 hours at $1052^{\circ} \mathrm{C}(7075)$, 


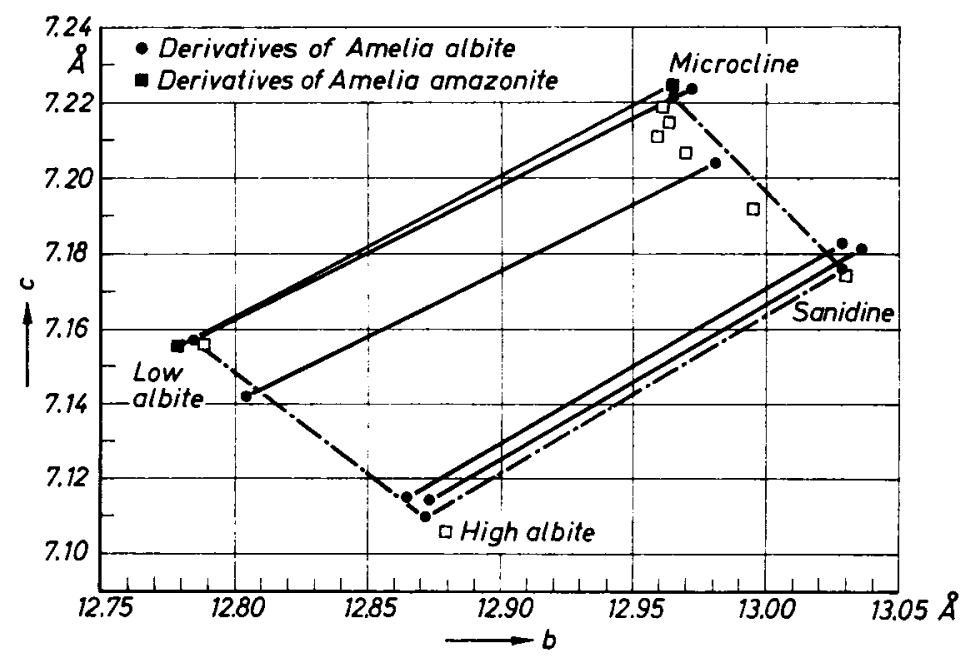

Fig. 1. $b$ and $c$ cell dimensions of end-member alkali feldspars. Solid lines connect exchange pairs derived from Amelia albite and from Amelia microcline (Table 1). Dot-dash lines connect preferred limiting reference values of STEwarT and RIBBE (1969, p. 450). Open squares indicate feldspars used in structure refinements (references in Thompson, 1969)

the diffraction pattern showed sharp, well-defined peaks of a typical high sanidine with $b=13.0295 \pm 0.0030, c=7.1771 \pm 0.0019 \AA$, and a value of $Z$ of $0.12 \pm 0.02$ estimated as above.

\section{(c) Microcline solutions}

Microcline-low-albite crystalline solutions were prepared from natural microcline (var. amazonite, Rutherford mine, Amelia, Va.) because of its greater resistance to Al-Si disordering under prolonged heating (SPENCER, 1937, p. 480; RAO, 1959). Sodium and potassium derivatives of this material ( $150 \mathrm{~g}$ each, -100 to $+400 \mathrm{mesh})$ were first prepared by ion exchange in fused reagent $\mathrm{NaCl}$ and $\mathrm{KCl}$ in platinum crucibles ${ }^{1}$. The crystalline solutions were then prepared by

1 The bright green color of the Amelia amazonite is lost during fused-salt exchange, which is consistent with the experimental data of OFTEDal (1957). Kastaer (1969) observed that the K-rich phase of the amazonite emits a bright blue cathodoluminescence (see SMITH and STENSTrom, 1965) at $20 \mathrm{kV}$ both before and after ion exchange. It was also noted that the intensity of the luminescence varies directly with the $K$ and $R b$ content of the end members and homogenized solutions (Table 3) and can be used to detect $(\mathrm{K}+\mathrm{Rb}$ ) and (Na) 
"homogenizing" the alkali atoms of mechanical mixtures of these endmembers (HAFNER and LAves, 1957). The mixtures were heated in 4 to $15 \mathrm{~g}$ quantities in platinum crucibles for approximately 150 hours at $935 \pm 15^{\circ} \mathrm{C}$ in ceramic-lined furnaces which had not been used previously for fused salt studies (to minimize the possibility of external alkali contamination). Every 48 hours during homogenization each crucible was removed from the furnace and cooled. The powders were then remixed vigorously to promote uniform alkali distribution throughout the sample, and were replaced in the crucibles and returned to the furnaces for further heat treatment. The course of the homogenization process was monitored by diffraction patterns after each successive heat treatment.

Partial chemical analyses of the parent microcline, several $\mathrm{Na}$ and $K$ derivatives, and the homogenized mixtures are given in Tables 2 and 3 (compare Heich, 1962; Plyusnin, 1969, Table 4). The natural material (6308) has the bulk composition $\mathrm{K}_{0.82} \mathrm{Na}_{0.16} \mathrm{Rb}_{0.02} \mathrm{AlSi}_{3} \mathrm{O}_{8}$. Calcium was not detected by gravimetric analysis (see also Table 2 ) $^{2}$. The material is slightly perthitic, which accounts for most of the $\mathrm{Na}$ content, and it is assumed that the albite phase is at least as highly ordered as the microcline (MacKENzre and SmrTh, 1962). The albitepericline grid twinning in the $K$ phase of the parent material was not affected by the above exchange procedures.

The unit-cell parameters of these samples are summarized in Table 4 and compared with several independent determinations on the same materials kindly obtained by D. B. Strwart (open circles in Fig. 2) and with those of OrviLLe (1967) for homogenized derivatives of microcline from the Hugo, South Dakota pegmatite. Figure 2 emphasizes the major differences rather than the similarities in the

zoning in individual grains (M. KASTNER, pers. comm., 1970). Similar luminescence is not observed in natural Amelia albite or its exchange products (both of which contain less than $0.05 \% \mathrm{Rb}_{2} \mathrm{O}$ ).

2 Infrared spectra and thermal-analysis data for amazonite and ordinary microcline (Plyusnin, 1969, Figs.6 and 8) suggest that amazonite may contain hydronium, most likely in the alkali aite. Raman spectra obtained on the Amelia amazonite used in this study (6308) and an $\mathrm{NaCl}$-exchanged derivative (6443) showed no unequivocal evidence for hydronium in either, although Raman lines are present in the principal hydronium bending and stretching frequency ranges in both materials (Raman spectra were obtained between 2.5 and $50 \mu \mathrm{m}$ on powdered material at room temperature using a Spectra-Physics-Model-700 instrument with an argon laser source, $300 \mathrm{~mW}$ at $5145 \AA$; details will be reported elsewhere). 
Table 4. Unit-cell parameters of microcline crystalline solution

Least-squares standard errors as defined by BLRN HAM (1962) are given below each parameter. Refinements numbered in italles were obtained by D. B. STEWART (1965, written comm.) with fluorite as an Internal standard $(a=5.4620 \AA)$

\begin{tabular}{|c|c|c|c|c|c|c|c|c|c|c|}
\hline $\begin{array}{l}\text { Sample } \\
\text { Refinen } \\
\text { Numbe }\end{array}$ & $\begin{array}{l}\text { ment No } \\
\text { er of line }\end{array}$ & & $\begin{array}{l}\text { Composition } \\
\mathbf{K} /(\mathbf{K}+\mathbf{N a})\end{array}$ & $\begin{array}{c}a \\
(\AA)\end{array}$ & $\begin{array}{c}b \\
(\AA)\end{array}$ & $\begin{array}{c}c \\
(\AA)\end{array}$ & $\left.{ }^{a}\right)$ & 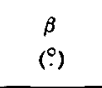 & $\begin{array}{l}\gamma \\
\left({ }^{\circ}\right)\end{array}$ & $\begin{array}{c}\boldsymbol{V} \\
\text { (cal/bar) }\end{array}$ \\
\hline 6420 & R222 & 21 & 0.0016 & $\begin{array}{r}8.1413 \\
\pm .0052\end{array}$ & $\begin{array}{r}12.7743 \\
.0072\end{array}$ & $\begin{array}{r}7.1551 \\
.0035\end{array}$ & $\begin{array}{r}94.105 \\
.053\end{array}$ & $\begin{array}{r}116.606 \\
.083\end{array}$ & $\begin{array}{r}87.741 \\
.048\end{array}$ & $\begin{array}{r}2.3883 \\
.0026\end{array}$ \\
\hline 6455 & R 192 & 8 & 0.0194 & $\begin{array}{r}8.1336 \\
.0058\end{array}$ & $\begin{array}{r}12.7790 \\
.0099\end{array}$ & $\begin{array}{r}7.1561 \\
.0041\end{array}$ & $\begin{array}{r}94.152 \\
.093\end{array}$ & $\begin{array}{r}116.640 \\
.037\end{array}$ & $\begin{array}{r}87.732 \\
.100\end{array}$ & $\begin{array}{r}2.3864 \\
.0028\end{array}$ \\
\hline 6440 & R 184 & 8 & 0.0148 & $\begin{array}{r}8.1418 \\
.0040\end{array}$ & $\begin{array}{r}12.7759 \\
.0088\end{array}$ & $\begin{array}{r}7.1552 \\
.0030\end{array}$ & $\begin{array}{r}93.983 \\
.057\end{array}$ & $\begin{array}{r}116.602 \\
.027\end{array}$ & $\begin{array}{r}87.912 \\
.059\end{array}$ & $\begin{array}{r}2.3893 \\
.0019\end{array}$ \\
\hline 6444 & R 271 & 32 & 0.0150 & $\begin{array}{r}8.1515 \\
.0042\end{array}$ & $\begin{array}{r}12.7842 \\
.0065\end{array}$ & $\begin{array}{r}7.1575 \\
.0025\end{array}$ & $\begin{array}{r}94.133 \\
.038\end{array}$ & $\begin{array}{r}116.633 \\
.025\end{array}$ & $\begin{array}{r}87.729 \\
.037\end{array}$ & $\begin{array}{r}2.3933 \\
.0021\end{array}$ \\
\hline 6450 & R 171 & 18 & 0.1078 & $\begin{array}{r}8.1964 \\
.0059\end{array}$ & $\begin{array}{r}12.7982 \\
.0065\end{array}$ & $\begin{array}{r}7.1719 \\
.0038\end{array}$ & $\begin{array}{r}93.737 \\
.051\end{array}$ & $\begin{array}{r}116.493 \\
.085\end{array}$ & $\begin{array}{r}87.813 \\
.051\end{array}$ & $\begin{array}{r}2.4181 \\
.0031\end{array}$ \\
\hline 6451 & R 177 & 27 & 0.1077 & $\begin{array}{r}8.2346 \\
.0058\end{array}$ & $\begin{array}{r}12.8314 \\
.0066\end{array}$ & $\begin{array}{r}7.1838 \\
.0040\end{array}$ & $\begin{array}{r}93.003 \\
.042\end{array}$ & $\begin{array}{r}116.278 \\
.034\end{array}$ & $\begin{array}{r}87.925 \\
.045\end{array}$ & $\begin{array}{r}2.4459 \\
.0032\end{array}$ \\
\hline 6447 & R 176 & 14 & 0.3014 & $\begin{array}{r}8.2908 \\
.0036\end{array}$ & $\begin{array}{r}12.8515 \\
.0037\end{array}$ & $\begin{array}{r}7.1876 \\
.0027\end{array}$ & $\begin{array}{r}92.569 \\
.032\end{array}$ & $\begin{array}{r}116.010 \\
.022\end{array}$ & $\begin{array}{r}87.708 \\
.028\end{array}$ & $\begin{array}{r}2.4740 \\
.0020\end{array}$ \\
\hline 6448 & R 167 & 17 & 0.3958 & $\begin{array}{r}8.3350 \\
.0036\end{array}$ & $\begin{array}{r}12.8775 \\
.0090\end{array}$ & $\begin{array}{r}7.2017 \\
.0023\end{array}$ & $\begin{array}{r}92.049 \\
.037\end{array}$ & $\begin{array}{r}116.098 \\
.020\end{array}$ & $\begin{array}{r}87.862 \\
.067\end{array}$ & $\begin{array}{r}2.4941 \\
.0015\end{array}$ \\
\hline 6441 & R178 & 30 & 0.4741 & $\begin{array}{r}8.3680 \\
.0050\end{array}$ & $\begin{array}{r}12.9055 \\
.0051\end{array}$ & $\begin{array}{r}7.2043 \\
.0041\end{array}$ & $\begin{array}{r}91.534 \\
.042\end{array}$ & $\begin{array}{r}115.922 \\
.033\end{array}$ & $\begin{array}{r}87.831 \\
.039\end{array}$ & $\begin{array}{r}2.1564 \\
.0032\end{array}$ \\
\hline $6453 \mathrm{E}$ & R 165 & 23 & 0.4988 & $\begin{array}{r}8.3893 \\
.0062\end{array}$ & $\begin{array}{r}12.9204 \\
.0062\end{array}$ & $\begin{array}{r}7.2071 \\
.0043\end{array}$ & $\begin{array}{r}91.535 \\
.055\end{array}$ & $\begin{array}{r}115.954 \\
.038\end{array}$ & $\begin{array}{r}87.684 \\
.046\end{array}$ & $\begin{array}{r}2.5258 \\
.0034\end{array}$ \\
\hline 6434 & R164 & 38 & 0.6240 & $\begin{array}{r}8.4380 \\
.0024\end{array}$ & $\begin{array}{r}12.9493 \\
.0024\end{array}$ & $\begin{array}{r}7.2123 \\
.0017\end{array}$ & $\begin{array}{r}91.088 \\
.02 \theta\end{array}$ & $\begin{array}{r}115.954 \\
.016\end{array}$ & $\begin{array}{r}87.709 \\
.025\end{array}$ & $\begin{array}{r}2.5482 \\
.0013\end{array}$ \\
\hline 6434 & R 755 & 22 & 0.6240 & $\begin{array}{r}8.4316 \\
.0038\end{array}$ & $\begin{array}{r}12.9478 \\
.0046\end{array}$ & $\begin{array}{r}7.2080 \\
.0018\end{array}$ & $\begin{array}{r}91.071 \\
.052\end{array}$ & $\begin{array}{r}115.970 \\
.025\end{array}$ & $\begin{array}{r}87.640 \\
.039\end{array}$ & $\begin{array}{r}2.5440 \\
.0024\end{array}$ \\
\hline 6449 & R 163 & 30 & 0.6868 & $\begin{array}{r}8.4698 \\
.0022\end{array}$ & $\begin{array}{r}12.9651 \\
.0017\end{array}$ & $\begin{array}{r}7.2078 \\
.0018\end{array}$ & $\begin{array}{r}90.850 \\
.027\end{array}$ & $\begin{array}{r}115.910 \\
.015\end{array}$ & $\begin{array}{r}87.777 \\
.025\end{array}$ & $\begin{array}{r}2.5586 \\
.0013\end{array}$ \\
\hline 6449 & R 754 & 16 & 0.6868 & $\begin{array}{r}8.4937 \\
.0074\end{array}$ & $\begin{array}{r}12.9514 \\
.0055\end{array}$ & $\begin{array}{r}7.2032 \\
.0029\end{array}$ & $\begin{array}{r}90.863 \\
.062\end{array}$ & $\begin{array}{r}115.946 \\
.038\end{array}$ & $\begin{array}{r}87.791 \\
.062\end{array}$ & $\begin{array}{r}2.5625 \\
.0041\end{array}$ \\
\hline 6442 & R162 & 27 & 0.7953 & $\begin{array}{r}8.5138 \\
.0031\end{array}$ & $\begin{array}{r}12.0653 \\
.0030\end{array}$ & $\begin{array}{r}7.2119 \\
.0019\end{array}$ & $\begin{array}{r}90.774 \\
.034\end{array}$ & $\begin{array}{r}115.921 \\
.021\end{array}$ & $\begin{array}{r}87.708 \\
.028\end{array}$ & $\begin{array}{r}2.5748 \\
.0015\end{array}$ \\
\hline 6442 & R 705 & 18 & 0.7953 & $\begin{array}{r}8.5341 \\
.0045\end{array}$ & $\begin{array}{r}12.0676 \\
.0043\end{array}$ & $\begin{array}{r}7.2157 \\
.0018\end{array}$ & $\begin{array}{r}90.790 \\
.033\end{array}$ & $\begin{array}{r}115.881 \\
.029\end{array}$ & $\begin{array}{r}87.718 \\
.035\end{array}$ & $\begin{array}{r}2.5837 \\
.0025\end{array}$ \\
\hline 6439 & R161 & 36 & 0.8986 & $\begin{array}{r}8.5553 \\
.0022\end{array}$ & $\begin{array}{r}12.9674 \\
.0013\end{array}$ & $\begin{array}{r}7.2191 \\
.0015\end{array}$ & $\begin{array}{r}90.629 \\
.018\end{array}$ & $\begin{array}{r}115.957 \\
.014\end{array}$ & $\begin{array}{r}87.751 \\
.018\end{array}$ & $\begin{array}{r}2.5806 \\
.0012\end{array}$ \\
\hline 6439 & R753 & 27 & 0.8986 & $\begin{array}{r}8.5576 \\
.0021\end{array}$ & $\begin{array}{r}12.9600 \\
.0033\end{array}$ & $\begin{array}{r}7.2183 \\
.0014\end{array}$ & $\begin{array}{r}90.650 \\
.029\end{array}$ & $\begin{array}{r}115.952 \\
.016\end{array}$ & $\begin{array}{r}87.732 \\
.028\end{array}$ & $\begin{array}{r}2.5886 \\
.0016\end{array}$ \\
\hline 6427 & R137 & 15 & 0.9954 & $\begin{array}{r}8.5099 \\
.0045\end{array}$ & $\begin{array}{r}12.0652 \\
.0027\end{array}$ & $\begin{array}{r}7.2246 \\
.0035\end{array}$ & $\begin{array}{r}90.671 \\
.043\end{array}$ & $\begin{array}{r}115.011 \\
.029\end{array}$ & $\begin{array}{r}87.699 \\
.040\end{array}$ & $\begin{array}{r}2.6056 \\
.0020\end{array}$ \\
\hline
\end{tabular}


three sets of data, and illustrates the uncertainty with which the $b$-c composition relations are presently known for the highly ordered lowalbite-microcline series. In other respects, ORvILLE's results and the present data are in good agreement [see, for example, $(\overline{2} 01) d$ values in Fig. 3 of WaldbaUm and Thompson, 1968]. It is not likely that the differences can be attributed to the rubidium in the present samples (see Martin and Lagache, 1970).

The cell parameters in Tables 1 and 4 were determined by leastsquares refinement of $\mathbf{x}$-ray diffraction data using the digital computer program LCLSQ of BURNHAM (1962); the uncertainties reported in the

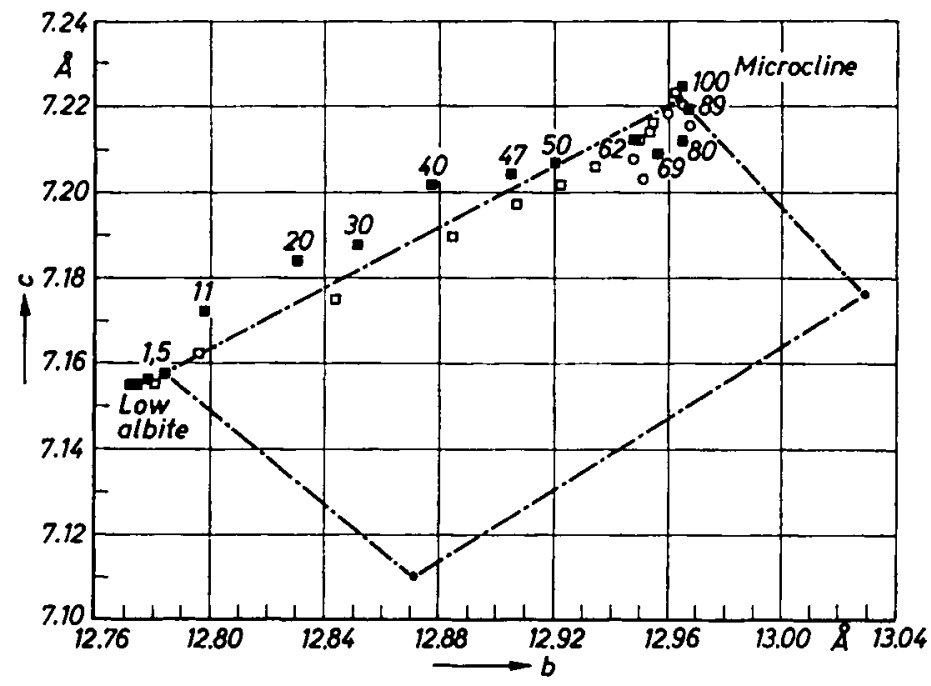

Fig. 2. $b$ and $c$ cell dimensions of microcline solutions. Filled squares are from this study (Table 4); numbers denote mole- $\% \mathrm{~K} /(\mathrm{K}+\mathrm{Na})$. Open squares are from Table $2 A$ of Orville (1967). Dot-dash lines are the same as in Fig. 1

cell parameters are least-squares standard errors as defined by BuRNHAM. The data were obtained with a Philips $x$-ray goniometer (model 42201) with Ni-filtered copper radiation, and only lines that could be indexed unambiguously were refined. Each sample was mixed with semiconductor-grade silicon as an internal standard and then deposited on a glass slide with collodion as a binder to give a permanent powder mount. The cell dimension $\left(5.43054 \pm 0.00017 \AA\right.$ at $\left.25^{\circ} \mathrm{C}\right)$ assigned to the silicon (analysis: $99.999 \% \mathrm{Si}$, less than $0.003 \mathrm{ppm} \mathrm{B}$; from United Mineral and Chemical Corporation, New York), and the $x$-ray wave- 
lengths used are from Parrish (1960). Two forward and reverse scans were made at $t^{\circ} 2 \theta$ per minute in the range 20 to 60 degrees $2 \theta$ at a chart speed of one inch per minute. The diffractometer was operated with a Geiger sensing element, $1^{\circ}$ scatter and divergence slits, 0.003 inch receiving slit, and usually with a time constant of 8 seconds, a scale factor of 1 , and multiplier of 4 .

A least-squares formulation of the molar volumes in Table 4 gave:

$\vec{V}=2.38505( \pm .0006)+0.21878( \pm .0010) N_{2}+0.1101( \pm .0036) N_{1} N_{2}$

in cal/bar-mole ${ }^{3}$ (STEwaRT's refinements $R 704, R 705, R 753, R 754$, and $\mathrm{R} 755$ not included), where $N_{1}$ and $N_{2}$ are mole fraction $\mathrm{NaAlSi}_{3} \mathrm{O}_{8}$ and $\mathrm{KAlSi}_{3} \mathrm{O}_{8}$, respectively. Inclusion of STEWART's five refinements gave:

$\bar{V}=2.38497( \pm .0006)+0.21962( \pm .0009) N_{2}+0.1096( \pm .0033) N_{1} N_{2}$.

These results are in good agreement with ORVILLE's (1967, Table 2 A) data from which we obtained:

$\bar{V}=2.38116( \pm .0020)+0.21794( \pm .0025) N_{2}+0.1226( \pm .0090) N_{1} N_{2}$.

Strict application of the Gauss criterion (Worthing and GEFFNer, 1943, p. 260) to the standard deviations of fit of higher-order formulations suggest that cubic or higher-order fits are not justified by the data.

\section{(d) Further observations on alkali homogenization}

The $\mathrm{K}$ and Na derivatives of Amelia microcline were also subjected to the above homogenization procedures as control samples to check for possible Al-Si disordering or alkali contamination. Cell parameters in Table 4 for "homogenized" (6455) and "unhomogenized" (6426) albites, both $\mathrm{Na}$ derivatives, indicate no significant differences in the two materials. The cleavelandite variety of Amelia albite, on the other hand, shows fairly significant structural changes when subjected to similar heat treatment for 150 hours (McKIE and MCConnele, 1963).

3 The uncertainties (precision) given for all least-squares coefficients in this paper are "thermochemical uncertainties" (Rossini and Deming, 1939 ; Thomp. son and Waldbadm, 1969 b, Appendix A). Enough significant figures have been given here to avoid serious round-off errors in calculations based on the coefficients. The number of figures should not be interpreted as an indication of the precision or accuracy of the results. One cal $/ \mathrm{bar}=41.840 \mathrm{~cm}^{3}$. 
The $\mathrm{K}$ derivatives 6427 (a single-exchange derivative) and $6442 \mathrm{KX}$ (prepared first as a K-Na solution by homogenization and later reexchanged in $\mathrm{KCl}$ ) also show no $\mathrm{x}$-ray evidence for disordering. The $\mathrm{K} /(\mathrm{K}+\mathrm{Na})$ ratios calculated from the alkali analyses in Table 3 agree within \pm 1 mole $-\%$ with those calculated from the weights of the end members in the initial mixtures.

The sharpness of individual $x$-ray peaks and the smooth relationships of the refined cell parameters with composition suggests that a high percentage of each of the grains must be near the bulk composition of a given mixture. However, electron-microprobe analyses obtained on 15 to 30 grains of each sample indicate that a few percent of the grains in some samples range in composition as much as two to three times that shown for $6453 \mathrm{~F}$ in Fig. 3. This is equivalent to a range as large as $\pm 10 \mathrm{~mole}-\%$ in each sample, and is by far the greatest single source of uncertainty in the experimental data for $6434,6441,6442$, 6447,6448 , and 6449 .

The difficulties in obtaining complete homogenization were not as serious as those noted by $R_{A O}$ (1959), probably because the same initial natural material was used to prepare both end-member constituents of the mechanical mixtures (see also Orvinle, 1967; and Wright and STEWART, 1968). However, the microprobe data clearly demonstrate that the presence of a single sharp, narrow $x$-ray line such as $(\overline{2} 01)$ is not a sufficient criterion for complete homogeneity. This was noted for the samples referred to above and in particular for an equimolar mechanical mixture $(6453 \mathrm{~A})$ which was heated for $24,49,93,191$, and 363 hours as above at $940 \pm 10^{\circ} \mathrm{C}$. The $(\overline{2} 01)$ peaks obtained under identical instrumental conditions for samples $6453 \mathrm{C}$ ( 49 hours) through $6453 \mathrm{~F}$ (363 hours) are virtually indistinguishable in position, width, and sharpness, yet the electron-microprobe analyses for $\mathrm{Na}$ and $\mathrm{K}$ shown in Fig. 3 suggest that complete alkali homogenization required considerably more than 49 hours.

The coarse grain size and large quantities of the materials homogenized in this study did not permit the use of pressed pellets of the mechanical mixtures; the powders were simply poured into the crucibles. This is most likely the main reason for the lack of uniform homogenization. There is no evidence in the electron-microprobe results (such as texture or a bimodal distribution of analyses) to suggest that $920^{\circ} \mathrm{C}$ is subcritical for this feldspar series, or that the phases unmixed after removal from the furnace as suggested by BARTH $(1965$, p. 24). Heterogeneity appears to be principally confined to the larger grains, 
and usually takes the form of concentric zoning. New $x$-ray diffraction patterns obtained five years after synthesis confirm that phase separation has not taken place, although the microprobe data which were obtained both in 1968 and 1970 are more reliable in this respect.
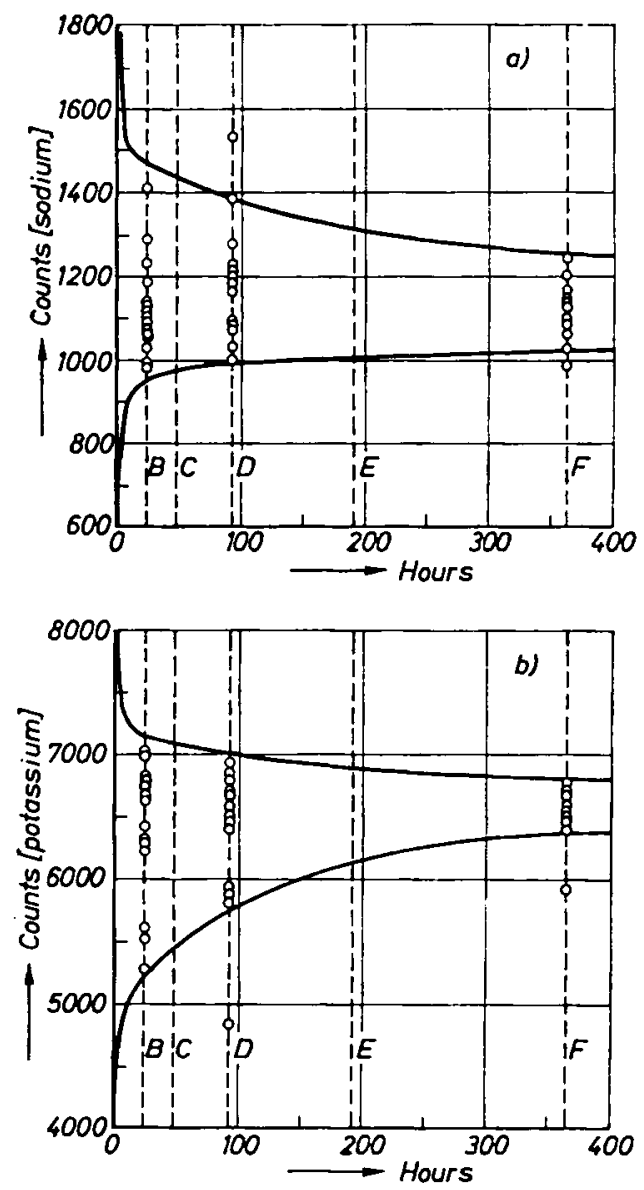

Fig. 3. Electron-microprobe analytical data showing the effect of time of homogenization (at $940 \pm 10^{\circ} \mathrm{C}$ ) on the distribution of $\mathrm{Na}$ and $\mathrm{K}$ in sample 6453 [50 mole- $\% \mathrm{~K} /(\mathrm{K}+\mathrm{Na})]$. The range of counts for $6453 \mathrm{~F}$ is comparable to the $\mathrm{Na}$ and $\mathrm{K}$ end-member derivatives of the amazonite which yielded a $\mathrm{Na}$ range of \pm 180 counts (at 2400 counts) and a range for $K$ of \pm 500 counts (at 11900) under the same instrumental conditions on the same day. Data were obtained using an Applied Research Laboratories, Inc., Model EMX microprobe operated at $20 \mathrm{kV}$ with a $20 \mathrm{nA}$ sample current. Counts refer to a time interval of constant electron flux (10000 counts). Grain size ranged from 20 to $100 \mu \mathrm{m}$; beam diameter about $4 \mu \mathrm{m} ; 16$ individual grains of each sample analyzed 


\section{Calorimetry}

The solution calorimeter used in this investigation was described in detail by RoBIE (1965) and WaldBaum (1966). Certain experimental and numerical procedures not previously published are summarized below.

\section{(a) Procedures}

In each heat-of-solution run the calorimeter vessel was loaded with a new charge of $940.10 \pm 0.01 \mathrm{~g}$ reagent-grade hydrofluoric acid (J. T. Baker and Fisher), so that the vessel was always filled to the same level. To maintain a basis for interlaboratory comparison, the amount and concentration $(20.1 \%)$ of the acid used here were the same as those used by other laboratories previously engaged in HF solution calorimetry (KING, 1951; KraceK and Neuvonen, 1952).

Each feldspar sample is contained inside the calorimeter in a hollow teflon stirring impeller, so that the sample is initially isolated from the acid (WALDBAUM and RoBIE, 1970). In previous studies on silicates, the samples were introduced into the acid by enclosing them in gelatin capsules and dropping them down a tube into the calorimeter at the appropriate time. In this study, the samples were introduced by pushing on a spring-loaded plunger which forced out two protective gold-foil disks and the sample into the acid. With the internal sample container, silicate powders mix freely with the acid within five seconds after release. The reaction time of feldspar particles was usually on the order of 15 to 60 minutes for the size fractions used in this study.

KRACEK and Neuvonen (1952) reported the formation of both crystalline and gelatinous precipitates in some of their calorimetric runs on plagioclase feldspars. Therefore, at the end of each solution run the acid, sample container, and calorimeter were examined carefully for unreacted material or precipitates formed in the reaction. We found no evidence to suggest that any undissolved feldspar or precipitates were in the calorimeter at the end of the experiments. The final solutions were water-clear and no deposits were noted on the inner surfaces of the calorimeter vessel. KRACEK and NeUvoneN's results are partly explained by the fact that their feldspar samples contained substantial

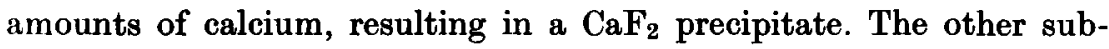
stances noted in their experiments, although apparently not crystalline feldspar, may have been incompletely-reacted acid-leached feldspar. The use of water-elutriated fines as samples and the use of gelatin capsules to contain the samples are recognized as sources of error in HF 
solution calorimetry (CoughLIN, 1962), in that part of the sample may become armored by gelatin or a precipitate. The present use of an internal sample container constructed of inert materials, and the use of relatively coarse-grained samples appears to promote complete reaction.

\section{(b) Thermometry}

The temperature sensor of the calorimeter is a copper resistance thermometer having a sensitivity of 1100 microvolts per degree, and the heater used for electrical calibration of the calorimeter is a manganin

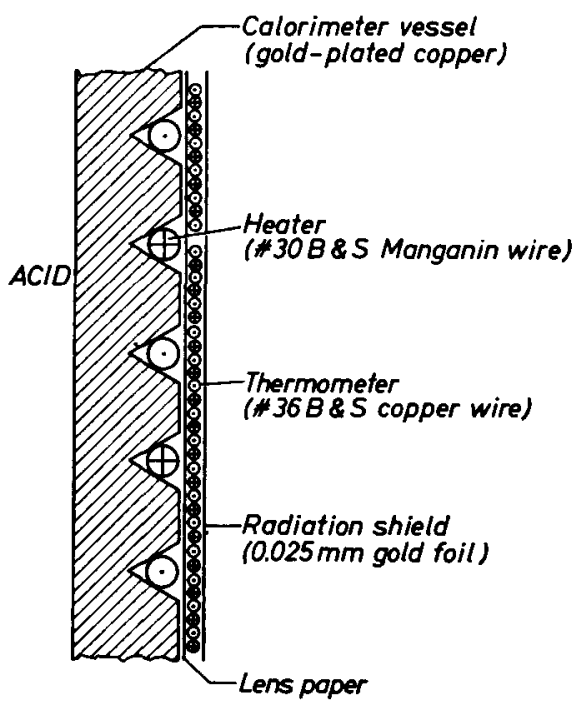

Fig.4. Heater and thermometer configuration

coil. The heater and thermometer are both wound as bifilar coils directly on the outer surface of the calorimeter (Fig.4), and are thus protected from corrosion by the acid-a problem frequently encountered in earlier solution calorimeters. This design also ensures that the thermometer integrates the temperature over the outer surface of the calorimeter vessel, and that the superheating effects on the surface due to the heater are smaller in magnitude and more uniformly distributed (see for example GUNN, 1964) and therefore can be conveniently measured. This arrangement of heater and thermometer provides considerable improvement in the accuracy of evaluating the heat-exchange corrections. 
The copper thermometer was calibrated in November, 1963 at the ice point $\left(0.00^{\circ} \mathrm{C}\right)$ and against a platinum resistance thermometer (MEYers, 1932, Serial No. 231) which had been calibrated at fixed points of the International Practical Temperature Scale of 1948 (IPTS-48; Stimson, 1961) by the National Bureau of Standards. For calibration of the copper thermometer, the plunger rod of the calorimeter (RoBIE, 1965, Fig. 1) was removed and the platinum thermometer was inserted directly into the calorimeter vessel which contained distilled water. The copper-platinum calibration points were obtained near $16,30,37,55$, and $69^{\circ} \mathrm{C}$. A least-squares fit to the original calibration data gave the following new formulation:

$R_{\theta}=R_{0}\left[1+4.25122\left(10^{-3}\right) \theta+13.0159\left(10^{-7}\right) \theta^{2}-1.32596\left(10^{-8}\right) \theta^{3}\right]$

for the copper thermometer, where $\theta$ denotes temperature on IPTS-48. The coefficients in (2) were obtained by fitting the quantity $\left[\left(R_{\theta} / R_{0}\right)-1\right] / \theta$ as a simple power series in $\theta$. This numerical procedure has the effect of forcing all copper resistance values to be based on the measured resistance at the ice point $\left(R_{0}=262.59910 \pm 0.00025 \mathrm{ohms}\right)$. A formulation of higher than third order is not warranted by the data. Equation (2) reproduces IPTS-48 accurately within $\pm 0.01 \%$ from 0 to $70^{\circ} \mathrm{C}$, and supercedes that in WALDBAUM $(1966$, p. 79) which was obtained by graphical methods.

\section{(c) Reduction of data}

The appropriate heat-exchange correction equations for an isoperibolic (temperature of surroundings held constant) calorimeter were derived from the relations given by Coops, JESSUP, and VAN NES (1956) and are summarized in WALDBAOM (in prep.). The equations take advantage of the fact that our heat-exchange modulus, $k$, is considerably less than that of air-jacketed calorimeters of similar size (CovGHLIN, 1962), so that the temperature-time curves are linear over periods of 100 to 200 minutes (five times longer than the actual rating periods). In other hydrofluoric-acid solution calorimeters (ToRaEson and Sahama, 1948; Hummer and Schwiete, 1959; Fitzsimmons and KIRK BRIDE, 1970) the value of $k$ is so large that the temperature-time curves show noticeable curvature even within one-half degree of the adiabatic temperature of the system. As a result, such experimental data must be converted to a logarithmic form and re-plotted (CovGH- 
LIN, 1962) which makes 'real-time' evaluation of the temperature-time curves difficult and is an additional source of error in final reduction of the data. The present calorimeter represents a significant improvement over the air-jacketed calorimeter because the data needed for computing the uncorrected temperature rise and heat-exchange corrections can be obtained directly from the recorder charts.

In correcting the observed temperature rise for heat exchange, the heat capacity and $k$ of the calorimeter were not assumed to be constant from one experiment to the next (as is often the procedure), but were computed from new calibration data obtained in each run. An additional small correction was added to the usual heat-exchange correction (NEwTON's cooling law) to account for superheating of the outer surface of the calorimeter (Cole et al., 1960; WALdBaUM, 1966; Stout, 1968) during electrical calibration. Superheating occurs because the heater is located between the thermometer and the wall of the calorimeter vessel (Fig.4), so that the thermometer and radiation shields, as well as the copper vessel and its contents, are heated. Since the electrical heating is not transferred instantaneously to the fluid inside the vessel, the outer surface of the calorimeter tends to superheat by about $0.04^{\circ} \mathrm{C}$ above the temperature of the fluid. The need to correct for this effect arises from the fact that it is the temperature of the outer surface that is referred to in the NEWTON's law corrections. This correction amounted to +0.02 percent of the total temperature rise compared with an average of \pm 0.4 percent contributed by the simple Newton's law correction alone.

The heat-exchange correction for dissolution was computed directly by trapezoidal integration of data recorded at 30-second intervals over periods of $1 / 2$ to 3 hours. The magnitudes of the corrections are listed in Tables 5 through 8 as percentage of the corrected temperature rise.

The heat capacity of the acid and solid parts of the calorimeter vary with temperature during a run, and this variation must be taken into account when assigning the heat of solution to a specific temperature. The temperature coefficient of the heat capacity of the calorimeter was determined in several separate experiments, and appears to be the same for the system before release of the sample as that of the system after sample release, although a difference might be expected due to a slight change in the level of the fluid and due to the change in state of the sample from crystal to ionic species. The value of $0.436 \mathrm{cal} \mathrm{deg}^{-2}$ obtained here compares favorably with (and is expectedly somewhat larger due to gold, teflon, copper, and other materials 
Na-K mixing and polymorphism in the alkali feldspars

Table 5. Heat of solution data for Amelia albite and Na deritative

\begin{tabular}{|c|c|c|c|c|c|c|c|c|}
\hline $\begin{array}{l}\text { Sample } \\
\text { number }\end{array}$ & Descriptlon* & $\frac{\mathbf{K}}{\mathbf{K}+\mathbf{N a}}$ & Run & Mass** & $\begin{array}{l}\text { Temp. } \\
\text { on } \\
\text { IPTS-68 }\end{array}$ & $\begin{array}{c}\% \\
\text { Correctlon } \\
\text { due to } \\
\text { beat } \\
\text { exchange }\end{array}$ & $\begin{array}{c}-H_{\text {nol }} \\
\text { 8t } \\
T_{1}, T_{t}\end{array}$ & $\begin{array}{c}-\bar{H}_{\infty 1} \\
\text { (kcal/mole) } \\
\text { at } \\
\text { mesn } T\end{array}$ \\
\hline 6914 & $\begin{array}{l}\text { Low albite, Nc } \\
-400 \text { mesh }\end{array}$ & 0.0 & 153 & $1.08490 \mathrm{~g}$ & $\begin{array}{l}39.13558^{\circ} \mathrm{C} \\
39.81303\end{array}$ & 0.39 & $\begin{array}{l}2301.30 \mathrm{~J} / \mathrm{g} \\
2300.67\end{array}$ & $\begin{array}{l}149.883^{* 0} \\
149.819\end{array}$ \\
\hline 6314 & (as above) & 0.0 & 154 & 1.08328 & $\begin{array}{l}39.03041 \\
39.70847\end{array}$ & 0.13 & $\begin{array}{l}2389.49 \\
2390.05\end{array}$ & $\begin{array}{l}149.769 \\
149.780\end{array}$ \\
\hline 6306 & $-200 /+325$ mesh Nc & 0.0 & 123 & 1.08171 & $\begin{array}{l}49.04939 \\
49.73331\end{array}$ & -1.23 & $\begin{array}{l}2390.10 \\
2397.55\end{array}$ & $\begin{array}{l}149.808 \\
150.250\end{array}$ \\
\hline 6321 & $-325 /+400$ mesh Nc & 0.0 & 124 & 1.08197 & $\begin{array}{l}49.19687 \\
48.87126\end{array}$ & -0.13 & $\begin{array}{l}2390.47 \\
2390.54\end{array}$ & $\begin{array}{l}149.830 \\
149.811\end{array}$ \\
\hline 6314 & (as above) & 0.0 & 125 & 1.08312 & $\begin{array}{l}49.19022 \\
49.86551\end{array}$ & -0.01 & \begin{tabular}{|l|}
2392.34 \\
2393.75
\end{tabular} & $\begin{array}{l}149.047 \\
150.012\end{array}$ \\
\hline 6314 & (as sbove) & 0.0 & 152 & 1.08104 & $\begin{array}{l}48.79061 \\
49.48100\end{array}$ & -0.98 & \begin{tabular}{|l|}
2394.38 \\
2393.83
\end{tabular} & $\begin{array}{l}150.07 \theta \\
150.017\end{array}$ \\
\hline 6314 & (as above) & 0.0 & 127 & 1.08453 & $\begin{array}{l}59.26687 \\
59.93919\end{array}$ & 0.44 & $\begin{array}{l}2397.46 \\
2398.04\end{array}$ & $\begin{array}{l}150.268 \\
150.281\end{array}$ \\
\hline 6321 & (as above) & 0.0 & 128 & 1.07949 & $\begin{array}{l}59.21878 \\
59.88977\end{array}$ & -0.06 & $\begin{array}{l}2391.60 \\
2392.10\end{array}$ & $\begin{array}{l}149.901 \\
149.909\end{array}$ \\
\hline 6454 & $\begin{array}{l}\text { Low albite } \\
\text { EDNc: } 910,24, \mathrm{NaCl} \\
-160 /+200 \text { mesh }\end{array}$ & 0.0 & 122 & 1.08226 & $\begin{array}{l}48.93368 \\
49.62938 \\
48.93366 \\
49.62938\end{array}$ & $\begin{array}{l}-2.92 \\
-3.00\end{array}$ & $\begin{array}{l}2394.58 \\
2394.34 \\
2392.48 \\
2394.87\end{array}$ & $\begin{array}{l}150.088 \\
150.048 \\
149.956 \\
150.082\end{array}$ \\
\hline $6406 \mathrm{Cl}$ & $\begin{array}{l}\text { High albite } \\
\text { ANc: } 1060,668\end{array}$ & 0.0 & 141 & 0.39905 & $\begin{array}{l}49.58145 \\
49.83927\end{array}$ & 0.78 & $\begin{array}{l}2439.05 \\
2440.14\end{array}$ & $\begin{array}{l}152.868 \\
152.927\end{array}$ \\
\hline $6406 \mathrm{Cl}$ & (as above) & 0.0 & 145 & 0.50252 & $\begin{array}{l}49.56458 \\
49.87914\end{array}$ & 1.18 & $\begin{array}{l}2430.29 \\
2426.53\end{array}$ & $\begin{array}{l}152.320 \\
152.073\end{array}$ \\
\hline 6411 & $\begin{array}{l}\text { NaAlSI, } 0, \text { glass } \\
\text { FNe: } 1325,1\end{array}$ & 0.0 & 143 & 0.49918 & $\begin{array}{l}49.64375 \\
49.98236\end{array}$ & 0.59 & $\begin{array}{l}2617.50 \\
2616.49\end{array}$ & $\begin{array}{l}164.054 \\
163.977\end{array}$ \\
\hline 6\$11 & (as above) & 0.0 & 146 & 0.47455 & $\begin{array}{l}49.42226 \\
49.74723 \\
49.74723\end{array}$ & -0.17 & $\begin{array}{l}2624.90 \\
2621.39 \\
2620.94\end{array}$ & $\begin{array}{l}164.621 \\
164.284 \\
164.256\end{array}$ \\
\hline
\end{tabular}

- Symbols in parentheses Indicate synthesis history. See footnote and detalls in Tables 1 and 3. Minus 400-mesh fraction here does not Include particles remaining suspended in n-propyl slcohol after 5 minutes settling-time.

* Masses corrected to vacuum: density of feldspar 2.59 ; denslty of welghts $7.8 \mathrm{~g} / \mathrm{cm}^{\prime}$. Formuls welghts are bseed on 1966 tomic weights and atomic fractlons in col. 3, assuming that the phases conslst of only $\mathrm{NaAlSl}_{2} \mathrm{O}_{3}(262.2245 \mathrm{~g} / \mathrm{mole})$ and KAISl, $\mathrm{O}_{3}(278.3367 \mathrm{~g} / \mathrm{mole})$.

in the calorimeter) $0.31 \mathrm{cal} \mathrm{deg}^{-2}$ for the $940 \mathrm{~g}$ of $20.1 \%$ hydrofluoric acid alone (Roth and TrortzsCH, 1932).

All electrical measurements were recorded to 8 figures, utilizing 6 digits from the potentiometer dials and 3 digits from the null-detector (chart) with one digit overlap between the two instruments. A minimum of 9 significant figures were carried through the computations 


\begin{tabular}{|c|c|c|c|c|c|c|c|c|}
\hline $\begin{array}{l}\text { Sample } \\
\text { number }\end{array}$ & Description & $\frac{\mathbf{K}}{\mathbf{K}+\mathbf{N}_{\mathbf{a}}}$ & Run & Mass* & $\begin{array}{c}\text { Temp. } \\
\text { on } \\
\text { IPTS-68 }\end{array}$ & $\begin{array}{c}\% \\
\text { Correction } \\
\text { due to } \\
\text { heat } \\
\text { exchange }\end{array}$ & $\begin{array}{c}-H_{\text {nol }} \\
\text { at } \\
T_{1}, T_{t}\end{array}$ & $\begin{array}{c}-\bar{H}_{\text {ol }} \\
\text { (kcal/mole) } \\
\text { at } \\
\text { mean } T\end{array}$ \\
\hline 6452 & Microcline & 1.0 & 132 & $1.14683 \mathrm{~g}$ & $\begin{array}{l}49.20659^{\circ} \mathrm{C} \\
48.85753\end{array}$ & -0.05 & $\left|\begin{array}{l}2176.30 \mathrm{~J} / \mathrm{g} \\
2178.90\end{array}\right|$ & $\begin{array}{l}144.756 \\
144.906\end{array}$ \\
\hline 6452 & (as above) & 1.0 & 134 & 0.30197 & $\begin{array}{l}49.44567 \\
49.61758\end{array}$ & -0.43 & $\begin{array}{l}2173.89 \\
2175.79\end{array}$ & $\begin{array}{l}144.587 \\
144.707\end{array}$ \\
\hline 6452 & (as above) & 1.0 & 129 & 1.02354 & $\begin{array}{l}59.29832 \\
59.87820\end{array}$ & 0.15 & $\begin{array}{l}2182.98 \\
2183.17\end{array}$ & $\begin{array}{l}145.190 \\
145.191\end{array}$ \\
\hline 6452 & (as above) & 1.0 & 130 & 1.14285 & $\begin{array}{l}59.29376 \\
59.94062\end{array}$ & 0.09 & $\begin{array}{l}2180.59 \\
2182.58\end{array}$ & $\begin{array}{l}145.041 \\
145.151\end{array}$ \\
\hline 6457 & $\begin{array}{l}\text { Sanidine } \\
\text { EDANC: } 910,24, \mathrm{KCl}\end{array}$ & 1.0 & 138 & 0.29937 & $\begin{array}{l}49.63172 \\
49.80394\end{array}$ & 0.21 & $\begin{array}{l}2211.61 \\
2211.31\end{array}$ & $\begin{array}{l}147.096 \\
147.070\end{array}$ \\
\hline 6457 & (as above) & 1.0 & 144 & 0.25751 & $\begin{array}{l}49.62931 \\
49.77686\end{array}$ & 0.01 & 2200.34 & $\begin{array}{l}146.346 \\
146.281\end{array}$ \\
\hline 6460 & $\begin{array}{l}\text { KAlSi,O, glass } \\
\operatorname{ED}(6411): 810,24, \mathrm{KCl}\end{array}$ & 0.967 & 140 & 1.22916 & $\begin{array}{l}49.82345 \\
50.57193\end{array}$ & 1.25 & $\begin{array}{l}2369.88 \\
2367.16\end{array}$ & $\begin{array}{l}157.371 \\
157.162\end{array}$ \\
\hline 6460 & (as above) & 0.967 & 142 & 1.14000 & $\begin{array}{l}49.34448 \\
50.04541\end{array}$ & 0.51 & $\begin{array}{l}2373.22 \\
2371.92\end{array}$ & $\begin{array}{l}157.591 \\
157.479\end{array}$ \\
\hline
\end{tabular}

\footnotetext{
- See notes in Table 5.
}

using a digital computer source program written in double-precision arithmetic (IBM 7094, 16 significant figures). Temperatures were computed from (2) by Newton-Raphson iteration: the residual of iteration was set at $0.1 \mu \mathrm{deg}$. With the chart record and the use of doubleprecision arithmetic, we are reasonably certain of a precision of 7 significant figures in the computed temperatures and an accuracy of $0.00005^{\circ} \mathrm{C}$ in the computed temperature differences.

The temperatures reported in this paper have been corrected to IPTS-68 (BARBER, 1969) using the following formulation:

$$
\begin{aligned}
\theta & {\left[0.101816595-1.498414\left(10^{-5}\right) \theta\right] } \\
& =T^{\prime}\left[0.101821571-1.503389\left(10^{-5}\right) T^{\prime}\right]-6\left(10^{-8}\right)
\end{aligned}
$$

where $T^{\prime}$ is in ${ }^{\circ} \mathrm{C}$ and refers to a hypothetical platinum resistance thermometer calibrated on IPTS-68 ( $t^{\prime}$ of BARBER, 1969). Equation (3) is given in a form equivalent to combining (62) and (63a) of Dovalas (1969), and can be used with $\theta$ 's obtained from any IPTS-48 platinum thermometer from the ice point to the antimony point (derivation of 
the coefficients in the above equation will be discussed in a subsequent paper). Equation (9) of BARBER (1969) was used in the final step of correcting the data to IPTS-68.

\section{(d) Results}

The calorimetric data obtained in this study summarized in Tables 5 through 8 represent the results of 64 heat-of-solution experiments having two or more heat-capacity determinations (electrical calibrations) in each experiment. From each heat capacity, a value of $H_{\text {sol }}$ was calculated from the corrected temperature rise of dissolution. These quantities, given in $\mathrm{j} / \mathrm{g}$ in the tables, are assigned to the initial and final temperatures of dissolution in accord with RossinI (1956). These are the basic calorimetric results and are independent of the choice of atomic weights or the chemical analyses. The values in the last column of the tables are expressed as the defined calorie, equal to exactly 4.1840 joules, and were calculated with the assumption that the compositions of these samples are precisely on the $(\mathrm{Na}, \mathrm{K}) \mathrm{AlSi}_{3} \mathrm{O}_{8}$ join. No corrections were made for phase impurities (none were detected) or for minor element content. All sample weights are corrected to true mass. The values in $\mathrm{kcal} / \mathrm{mole}$ are assigned to the mean temperature of dissolution (in run 153 of Table 5, for example, $39.4743^{\circ} \mathrm{C}$ ). The data were obtained at $1 \mathrm{~atm}(1.013 \mathrm{bar})$ pressure.

\section{Temperature dependence and grain-size effects}

The data in Table 5 provide a tentative estimate of the dependence of the heats of solution of low albite and microcline on the mean

temperature of dissolution. Least-squares formulations of the data gave

$$
\bar{H}_{\text {8ol }}=-149.263( \pm .13)-0.0137( \pm .0025) T \mathrm{kcal} / \mathrm{mole}
$$

for low albite (samples 6306, 6314, and 6321), and

$$
\bar{H}_{\text {sol }}=-142.688( \pm .12)-0.0414( \pm .0022) T \mathrm{kcal} / \mathrm{mole}
$$

for microcline (sample 6452), where $T$ is in ${ }^{\circ} \mathrm{C}$. The temperature coefficients in (4) and (5) enable us to compare the present results with those of Kracek and NeUvonen (1952) obtained at $74.7^{\circ} \mathrm{C}$.

Equations (4) and (5) refer to heats of solution where the initial temperature of the sample is the same as the acid. Previous heat of solution measurements on quartz (summarized by HUMmeL and ScHWIETE, 1959) have given some indication of the variation of the 
Table 7. Heat of solution data for Amelia microcline $\mathrm{Na}$ and $\mathrm{K}$ derivatives and homogenized mixtures*

\begin{tabular}{|c|c|c|c|c|c|c|c|}
\hline $\begin{array}{l}\text { Sample } \\
\text { number }\end{array}$ & $\frac{\mathbf{K}}{\mathbf{K}+\mathbf{N a}}$ & Run & Mass & $\begin{array}{c}T_{1}, T_{\mathrm{l}} \\
\text { on } \\
\text { IPTS-68 }\end{array}$ & \begin{tabular}{|c|}
$0 \%$ \\
Cor- \\
rection \\
due to \\
heat \\
exchange
\end{tabular} & $\begin{array}{c}-H_{\text {sol }} \\
\text { at } \\
T_{1}, T_{t}\end{array}$ & $\begin{array}{c}-\bar{H}_{\text {sol }} \\
\text { (kcal/mole }) \\
\text { at } \\
\text { mean } T\end{array}$ \\
\hline \multirow[t]{3}{*}{6444} & .0150 & 82 & $1.01844 \mathrm{~g}$ & $\begin{array}{l}49.37341^{\circ} \mathrm{C} \\
50.00360\end{array}$ & 0.42 & $\begin{array}{l}2379.73 \mathrm{j} / \mathrm{g} \\
2381.98\end{array}$ & $\begin{array}{l}149.294 \\
149.412\end{array}$ \\
\hline & .0150 & 83 & $1.0036 \theta$ & $\begin{array}{l}49.40396 \\
50.02353\end{array}$ & 0.74 & $\begin{array}{l}2382.37 \\
2383.10\end{array}$ & $\begin{array}{l}149.459 \\
149.483\end{array}$ \\
\hline & .0150 & 84 & 0.92218 & $\begin{array}{l}49.36777 \\
49.93981\end{array}$ & 0.20 & $\begin{array}{l}2381.67 \\
2380.83\end{array}$ & $\begin{array}{l}149.415 \\
149.341\end{array}$ \\
\hline \multirow[t]{3}{*}{6450} & .1084 & 103 & 0.90958 & $\begin{array}{l}49.66249 \\
50.22085\end{array}$ & 0.63 & $\begin{array}{l}2368.67 \\
2368.80\end{array}$ & $\begin{array}{l}149.451 \\
149.439\end{array}$ \\
\hline & .1084 & 104 & 0.91270 & $\begin{array}{l}49.35605 \\
49.92012\end{array}$ & 0.16 & $\begin{array}{l}2373.63 \\
2372.62\end{array}$ & $\begin{array}{l}149.764 \\
149.680\end{array}$ \\
\hline & .1084 & 115 & 0.99991 & $\begin{array}{l}49.46246 \\
50.07846\end{array}$ & 0.55 & $\begin{array}{l}2373.77 \\
2375.91\end{array}$ & $\begin{array}{l}149.774 \\
149.887\end{array}$ \\
\hline \multirow[t]{4}{*}{6451} & .1977 & 101 & 1.01085 & $\begin{array}{l}49.38780 \\
50.00523\end{array}$ & 0.81 & $\begin{array}{l}2359.72 \\
2359.10\end{array}$ & $\begin{array}{l}149.699 \\
149.637\end{array}$ \\
\hline & .1977 & 102 & 1.00986 & $\begin{array}{l}49.27074 \\
49.89208\end{array}$ & 0.04 & $\begin{array}{l}2359.20 \\
2360.09\end{array}$ & $\begin{array}{l}149.666 \\
149.700\end{array}$ \\
\hline & .1977 & 111 & 1.01068 & $\begin{array}{l}49.22938 \\
49.85113\end{array}$ & -0.07 & $\begin{array}{l}2357.80 \\
2357.73\end{array}$ & $\begin{array}{l}149.577 \\
149.550\end{array}$ \\
\hline & .1977 & 112 & 1.01307 & $\begin{array}{l}49.31198 \\
49.93466\end{array}$ & 0.27 & $\begin{array}{l}2362.29 \\
2361.94\end{array}$ & $\begin{array}{l}149.862 \\
149.818\end{array}$ \\
\hline \multirow[t]{3}{*}{6447} & .3014 & 95 & 0.90319 & $\begin{array}{l}49.56344 \\
50.11103\end{array}$ & 0.74 & $\begin{array}{l}2341.11 \\
2339.97\end{array}$ & $\begin{array}{l}149.452 \\
149.360\end{array}$ \\
\hline & .3014 & 96 & 0.90226 & $\begin{array}{l}49.36948 \\
49.91860\end{array}$ & 0.31 & $\begin{array}{l}2338.36 \\
2338.97\end{array}$ & $\begin{array}{l}149.276 \\
149.296\end{array}$ \\
\hline & .3014 & 110 & 1.02422 & $\begin{array}{l}49.33836 \\
49.96110\end{array}$ & 0.51 & $\begin{array}{l}2341.59 \\
2343.39\end{array}$ & $\begin{array}{l}149.484 \\
149.676\end{array}$ \\
\hline
\end{tabular}

* See notes in Table 5 . 
Table 7. (Continued)

\begin{tabular}{|c|c|c|c|c|c|c|c|}
\hline $\begin{array}{l}\text { Sample } \\
\text { number }\end{array}$ & $\frac{K}{\mathbf{K}+\mathbf{N a}}$ & Run & Mass & $\begin{array}{c}T_{1}, T_{l} \\
\text { on } \\
\text { IPTS-68 }\end{array}$ & $\begin{array}{c}0 / 0 \\
\text { Cor- } \\
\text { rection } \\
\text { due to } \\
\text { heat } \\
\text { exchange }\end{array}$ & $\begin{array}{c}-H_{\text {sol }} \\
\text { at } \\
T_{1}, T_{1}\end{array}$ & $\left\{\begin{array}{c}-\vec{H}_{\mathrm{sol}} \\
(\mathrm{kcal} / \mathrm{mole}) \\
\text { at }: 1 \\
\text { mean } T\end{array}\right.$ \\
\hline \multirow[t]{3}{*}{6448} & .3958 & 97 & $1.00274 \mathrm{~g}$ & $\begin{array}{l}49.48725^{\circ} \mathrm{C} \\
50.08645\end{array}$ & 1.45 & $\begin{array}{l}2323.56 \mathrm{j} / \mathrm{g} \\
2324.21\end{array}$ & $\begin{array}{l}149.177 \\
149.198\end{array}$ \\
\hline & .3958 & 98 & 1.00382 & $\begin{array}{l}49.43971 \\
50.04357\end{array}$ & 0.61 & $\begin{array}{l}2318.00 \\
2320.18\end{array}$ & $\begin{array}{l}148.884 \\
148.938\end{array}$ \\
\hline & .3958 & 113 & 1.05249 & $\begin{array}{l}49.30887 \\
49.94567\end{array}$ & 0.20 & $\begin{array}{l}2322.95 \\
2326.27\end{array}$ & $\begin{array}{l}149.138 \\
149.329\end{array}$ \\
\hline \multirow[t]{3}{*}{6441} & .4741 & 91 & 1.00986 & $\begin{array}{l}49.40316 \\
50.00769\end{array}$ & 0.42 & $\begin{array}{l}2306.08 \\
2305.76\end{array}$ & $\begin{array}{l}148.751 \\
148.708\end{array}$ \\
\hline & .4741 & 92 & 1.01262 & $\begin{array}{l}49.39019 \\
49.99353\end{array}$ & 0.87 & $\begin{array}{l}2302.57 \\
2303.40\end{array}$ & $\begin{array}{l}148.524 \\
148.556\end{array}$ \\
\hline & .4741 & 119 & 0.99671 & $\begin{array}{l}49.31217 \\
49.91003\end{array}$ & 0.17 & $\begin{array}{l}2300.70 \\
2304.61\end{array}$ & $\begin{array}{l}148.404 \\
148.634\end{array}$ \\
\hline \multirow[t]{2}{*}{$6453 E$} & .4998 & $\mathbf{5 7}$ & 0.70490 & $\begin{array}{l}49.21070 \\
49.63733\end{array}$ & -0.77 & $\begin{array}{l}2300.04 \\
2300.12\end{array}$ & $\begin{array}{l}148.586 \\
148.575\end{array}$ \\
\hline & .4998 & 58 & 0.70568 & $\begin{array}{l}49.49792 \\
49.91885\end{array}$ & 0.71 & $\begin{array}{l}2300.16 \\
2301.25\end{array}$ & $\begin{array}{l}148.622 \\
148.649\end{array}$ \\
\hline \multirow[t]{4}{*}{6434} & .6240 & 88 & 1.00315 & $\begin{array}{l}49.62456 \\
50.21154\end{array}$ & 1.44 & $\begin{array}{l}2273.63 \\
2275.38\end{array}$ & $\begin{array}{l}147.970 \\
148.063\end{array}$ \\
\hline & .6240 & 89 & 1.00271 & $\begin{array}{l}49.53406 \\
50.12077\end{array}$ & 1.16 & $\begin{array}{l}2269.42 \\
2267.03\end{array}$ & $\begin{array}{l}147.696 \\
147.519\end{array}$ \\
\hline & .6240 & 90 & 1.00359 & $\begin{array}{l}49.40199 \\
49.99293\end{array}$ & 0.63 & $\begin{array}{l}2270.93 \\
2272.35\end{array}$ & $\begin{array}{l}147.794 \\
147.865\end{array}$ \\
\hline & .6240 & 108 & 1.00020 & $\begin{array}{l}49.40564 \\
49.99519\end{array}$ & 0.49 & $\begin{array}{l}2272.28 \\
2271.42\end{array}$ & $\begin{array}{l}147.881 \\
1.47 .805\end{array}$ \\
\hline \multirow[t]{2}{*}{6449} & .6868 & 99 & 1.00395 & $\begin{array}{l}49.52233 \\
50.10766\end{array}$ & 0.98 & $\begin{array}{l}2255.42 \\
2256.42\end{array}$ & $\begin{array}{l}147.330 \\
147.375\end{array}$ \\
\hline & .6868 & 100 & 1.00427 & $\begin{array}{l}48.41577 \\
50.00420\end{array}$ & 0.33 & $\begin{array}{l}2252.60 \\
2254.31\end{array}$ & $\begin{array}{l}147.146 \\
147.237\end{array}$ \\
\hline
\end{tabular}


Table 7. (Continued)

\begin{tabular}{|c|c|c|c|c|c|c|c|}
\hline $\begin{array}{l}\text { Sample } \\
\text { number }\end{array}$ & $\frac{\mathbf{K}}{\mathbf{K}+\mathbf{N a}}$ & Run & Mass & $\begin{array}{c}T_{1}, T_{1} \\
\text { on } \\
\text { IPTS-68 }\end{array}$ & \begin{tabular}{|c|}
$\%$ \\
Cor- \\
rection \\
due to \\
heat \\
exchange
\end{tabular} & $\begin{array}{c}-H_{\mathrm{aol}} \\
\text { at } \\
T_{1}, T_{t}\end{array}$ & $\left\{\begin{array}{c}-\bar{H}_{\text {sol }} \\
(\mathrm{kcal} / \mathrm{mole}) \\
\text { at } \\
\text { mean } T\end{array}\right.$ \\
\hline 6449 & .6868 & 116 & $1.02239 \mathrm{~g}$ & $\begin{array}{l}49.21872^{\circ} \mathrm{C} \\
49.82120\end{array}$ & -0.27 & $\begin{array}{l}2253.70 \mathrm{j} / \mathrm{g} \\
2255.96\end{array}$ & $\begin{array}{l}147.218 \\
147.345\end{array}$ \\
\hline 6442 & .7953 & 93 & 1.00561 & $\begin{array}{l}49.41826 \\
49.99945\end{array}$ & 0.54 & $\begin{array}{l}2226.70 \\
2227.64\end{array}$ & $\begin{array}{l}146.384 \\
146.426\end{array}$ \\
\hline & .7953 & 94 & 1.00826 & $\begin{array}{l}49.43884 \\
50.02193\end{array}$ & 0.42 & $\begin{array}{l}2224.97 \\
2224.88\end{array}$ & $\begin{array}{l}146.270 \\
146.244\end{array}$ \\
\hline & .7953 & 114 & 1.00885 & $\begin{array}{l}50.41597 \\
50.97645\end{array}$ & 4.37 & $\begin{array}{l}2220.34 \\
2220.90\end{array}$ & $\begin{array}{l}145.966 \\
145.983\end{array}$ \\
\hline 6439 & .8945 & 105 & 1.00219 & $\begin{array}{l}49.60126 \\
50.16784\end{array}$ & 1.50 & $\begin{array}{l}2200.15 \\
2198.83\end{array}$ & $\begin{array}{l}145.479 \\
145.372\end{array}$ \\
\hline & .8945 & 106 & 1.02059 & $\begin{array}{l}49.29704 \\
49.88166\end{array}$ & -0.03 & $\begin{array}{l}2193.61 \\
2194.66\end{array}$ & $\begin{array}{l}145.046 \\
145.096\end{array}$ \\
\hline & .8945 & 107 & 1.01388 & $\begin{array}{l}49.40139 \\
49.97892\end{array}$ & 0.61 & $\begin{array}{l}2195.36 \\
2200.56\end{array}$ & $\begin{array}{l}145.162 \\
145.486\end{array}$ \\
\hline & .8945 & 120 & 1.00109 & $\begin{array}{l}49.27591 \\
49.85035\end{array}$ & 0.02 & $\begin{array}{l}2202.10 \\
2201.30\end{array}$ & $\begin{array}{l}145.608 \\
145.535\end{array}$ \\
\hline 6427 & .9954 & 80 & 1.00469 & $\begin{array}{l}48.89646 \\
49.47958\end{array}$ & -2.48 & $\begin{array}{l}2167.39 \\
2167.41\end{array}$ & $\begin{array}{l}144.155 \\
144.136\end{array}$ \\
\hline 6438 & .9955 & 86 & 1.01182 & $\begin{array}{l}49.36587 \\
49.93677\end{array}$ & 0.04 & $\begin{array}{l}2163.14 \\
2161.4 \theta\end{array}$ & $\begin{array}{l}143.873 \\
143.744\end{array}$ \\
\hline \multirow{4}{*}{6446} & .9955 & 87 & 1.00573 & $\begin{array}{l}49.33469 \\
49.90302\end{array}$ & -0.02 & $\begin{array}{l}2164.94 \\
2167.97\end{array}$ & $\begin{array}{l}143.992 \\
144.175\end{array}$ \\
\hline & .9855 & 121 & 1.00479 & $\begin{array}{l}49.24444 \\
49.81431\end{array}$ & -0.19 & $\begin{array}{l}2168.84 \\
2171.54\end{array}$ & $\begin{array}{l}144.252 \\
144.412\end{array}$ \\
\hline & .9987 & 117 & 1.01105 & $\begin{array}{l}48.33454 \\
49.90551\end{array}$ & 0.11 & $\begin{array}{l}2167.81 \\
2165.44\end{array}$ & $\begin{array}{l}144.211 \\
144.033\end{array}$ \\
\hline & .9987 & 118 & 1.02557 & $\begin{array}{l}49.32321 \\
48.90290\end{array}$ & 0.15 & $\begin{array}{l}2170.86 \\
2169.13\end{array}$ & $\begin{array}{l}144.414 \\
144.279\end{array}$ \\
\hline
\end{tabular}


Table 8. Heat of solution data for a mechanical mixture of $\mathrm{Na}$ and $\mathrm{K}$ derivatives*

\begin{tabular}{|c|c|c|c|c|c|c|c|}
\hline $\begin{array}{l}\text { Sample } \\
\text { number }\end{array}$ & $\frac{\mathbf{K}}{\mathbf{K}+\mathbf{N a}}$ & Run & Mass & \begin{tabular}{|c} 
\\
$T_{1}, T_{\mathfrak{t}}$ \\
on \\
IPTS-68
\end{tabular} & \begin{tabular}{|c|}
$0 / 0$ \\
Cor- \\
rection \\
due to \\
heat \\
exchange
\end{tabular} & $\begin{array}{c}-H_{\text {sol }} \\
\text { at } \\
T_{1}, T_{\mathrm{r}}\end{array}$ & $\left\{\begin{array}{c}-\bar{H}_{\text {sol }} \\
(\mathrm{kcal} / \mathrm{mole}) \\
\text { at } \\
\text { mean } T\end{array}\right.$ \\
\hline \multirow[t]{3}{*}{$6453 \mathrm{~A}$} & .4998 & 55 & $1.12270 \mathrm{~g}$ & $\begin{array}{l}49.35378^{\circ} \mathrm{C} \\
50.01447\end{array}$ & 0.86 & $\begin{array}{l}2273.70 \mathrm{j} / \mathrm{g} \\
2275.34\end{array}$ & $\begin{array}{l}146.888 \\
146.971\end{array}$ \\
\hline & .4998 & 56 & 0.70092 & $\begin{array}{l}49.42266 \\
48.83559\end{array}$ & 0.82 & $\begin{array}{l}2276.11 \\
2277.10\end{array}$ & $\begin{array}{l}147.040 \\
147.089\end{array}$ \\
\hline & .4998 & 71 & 0.71008 & $\begin{array}{l}49.51411 \\
49.93188\end{array}$ & 0.60 & $\begin{array}{l}2269.80 \\
2270.07\end{array}$ & $\begin{array}{l}146.632 \\
146.634\end{array}$ \\
\hline
\end{tabular}

* See notes in Table 5.

heats of solution of silicates with temperature, but the principal effect that was observed in these studies resulted from the fact that the sample and acid were initially at different temperatures. The present results give a more accurate indication of the effect of temperature on the heat of solution alone, inasmuch as the small differences in heats of solution are not masked by the "sensible heat" correction (CovarIIN, 1962) and other uncertainties introduced by the use of gelatin capsules.

The present data also indicate that feldspar samples having particle sizes up to 100 microns can be used in hydrofluoric acid solution calorimetry provided the calorimeter has low heat-exchange characteristics and good thermal stability lasting for several hours. Although the use of different size fractions affected the reaction times by a factor of three (50 minutes in runs 124 and $125 ; 160$ minutes in run 122) and the heat-exchange corrections differ by as much as two orders of magnitude (Table 5, column VII), the heats of solution are in excellent agreement, showing no systematic variation within the limits of experimental error (compare Fitzsimmons and KIRKBRIDE, 1970, on silica glass). These results are important in eliminating several possible sources of systematic error which can result from surface effects such as adsorption of water, surface hydrolysis, and surface energy of the crystals when water-elutriated fines are used as samples (KRACEK and Nedvonen, 1952; Covahlin, 1962). 


\section{Enthalpy and internal energy of Al-Si disordering}

The difference in molar enthalpy between highly-ordered and highly-disordered polymorphs of $\mathrm{NaAlSi}_{3} \mathrm{O}_{8}$ and $\mathrm{KAISi}_{3} \mathrm{O}_{8}$ are obtained from the differences in their respective heats of solution (Table 9). KRACEK and NEUVONEN (1952) obtained hydrofluoric acid calorimetric data at $74.7^{\circ} \mathrm{C}$ on natural Amelia low albite, natural low albite from Varuträsk, Sweden, and on these same materials annealed for 2040 hours at $1050^{\circ} \mathrm{C}$ (F. C. KRACEK, unpublished notes, v. 9, p. 32). They obtained $2.20 \pm 0.16 \mathrm{kcal} / \mathrm{mole}$ for the difference between the high and low Amelia albite, and $2.43 \pm 0.30 \mathrm{kcal} / \mathrm{mole}$ for the Varuträsk samples, compared with $2.60 \pm 0.30 \mathrm{kcal} /$ mole obtained in this study.

HoLM and KLEPPA (1968) measured the heats of solution at $698^{\circ} \mathrm{C}$ of Amelia low albite and the same material heated 840 hours at $1045 \pm 5^{\circ} \mathrm{C}$ using a lead-cadmium-borate melt as the solvent. They also obtained high-temperature heat-capacity data on their low albite and on sample 6406-Cl of this study. Combining the two sets of measurements, HoLM and KLEPPA obtained $2.6 \pm 0.35 \mathrm{kcal} / \mathrm{mole}$ at $25^{\circ} \mathrm{C}$. No comparable data for microcline and sanidine have been obtained previously. More recent studies with the same calorimeter and some of the same samples (Hovis et al., 1970) reproduced the differences between high and low albite, and between sanidine and microcline within $50 \mathrm{cal} / \mathrm{mole}$.

Table 9. Summary of heats of solution of $\mathrm{Na}$ and $\mathrm{K}$ derivatives (cal/mole at $49.7^{\circ} \mathrm{C}$ )

\begin{tabular}{l|l|l|l|l|l|l|l}
\hline $\mathrm{NaAlSi}_{8} \mathrm{O}_{\mathrm{a}}$ & $H_{\text {sol }}$ & $\Delta \tilde{H}$ & $\Delta \bar{E}$ & $\mathrm{KAlSi}_{9} \mathrm{O}_{\mathrm{g}}$ & $\bar{H}_{201}$ & $\Delta \bar{H}$ & $\Delta \bar{E}$ \\
\hline
\end{tabular}

Amelis albite and derivatives

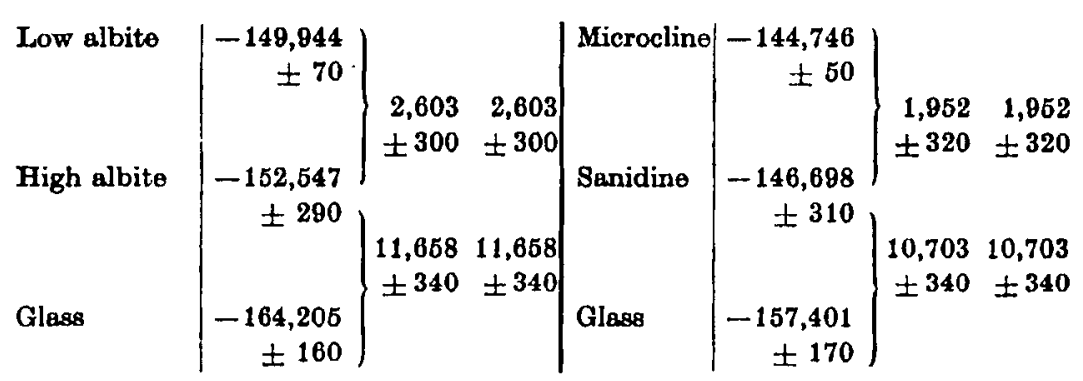

Derivatives of Amelia microcline (amazonito)

$\begin{aligned} & \text { Low albite } \\ & \left.\text { (Eq. 7, } N_{3}=0\right)\end{aligned}\left|\begin{array}{r}-149,408 \\ \pm 32\end{array}\right|-|-| \begin{aligned} & \text { Microcline } \\ & \left(N_{2}=1\right)\end{aligned}\left|\begin{array}{r}-144,178 \\ \pm 32\end{array}\right|-\mid-$ 
The differences in molar internal energy of the highly ordered and disordered polymorphs in Table 9 were calculated from the relation

$$
\bar{E}=\bar{H}-P \bar{V}
$$

using the volume data in Table 1 . From these values of $\Delta \bar{E}$ and $\Delta \bar{V}$, the values of $\Delta \bar{H}$ calculated for $10 \mathrm{kbar}$ and $25^{\circ} \mathrm{C}$ are $2.72 \mathrm{kcal}$ for high-low albite and $2.00 \mathrm{kcal} /$ mole for sanidine-microcline, neglecting the differences in compressibilities of the polymorphs (which have not as yet been determined).

The effect of temperature on the enthalpy difference of high and low albite is much larger than the effect of pressure. HoLM and KLEPPA (1968) measured $3.4 \pm 0.25 \mathrm{kcal}$ at $698^{\circ} \mathrm{C}$ and when extrapolated to higher temperatures (WALDBAUM, 1968) yield $3.9 \mathrm{kcal} / \mathrm{mole}$ at $1127^{\circ} \mathrm{C}$, or an increase of $50 \%$ from $25^{\circ} \mathrm{C}$ to the melting point of high albite. These results and the thermal expansion data of STEWART and voN LIмBach (1967) indicate that the vibrational properties of high and low albite must differ considerably at high temperatures as well as at room temperature (compare spectral data of LAVES and HAFNER, 1956, 1962).

\section{Enthalpy and internal energy of the glass phases}

The heats of solution of the glasses of $\mathrm{NaAlSi}_{3} \mathrm{O}_{8}$ and $\mathrm{KAISi}_{3} \mathrm{O}_{8} \mathrm{com}$ position are summarized in Table 9. KRACEK and NGovonen (1952) obtained similar data at $74.7^{\circ} \mathrm{C}$ on glass prepared from Amelia albite and Varuträsk albite. The differences in the glasses and the respective low albites (corrected to $49.7^{\circ} \mathrm{C}$ ) are 11.65 and $12.53 \mathrm{kcal} / \mathrm{mole} \mathrm{com-}$ pared with $14.26 \pm 0.20 \mathrm{kcal} /$ mole for Amelia albite and its glass determined in this study. HLabse and KuEPPA (1968) measured $15.08 \pm 0.38 \mathrm{kcal}$ for Amelia (low) albite and its glass, each dissolved in a lead borate melt at $691^{\circ} \mathrm{C}$. Their results yield $14.07 \pm 0.40 \mathrm{kcal} /$ mole when corrected to $49.7^{\circ} \mathrm{C}$.

The only comparable data for $\mathrm{KAlSi}_{3} \mathrm{O}_{8}$ are the hydrofluoric acid calorimetric results of TaMMANN (1903), who obtained a difference of $23 \pm 5 \mathrm{kcal} / \mathrm{mole}$ between a "microcline" and its glass, and by MüLEeT (1912) who measured a difference of $28 \pm 5 \mathrm{kcal} / \mathrm{mole}$ between an "adularia" and its glass. The reasons for the large discrepancies with the present results are not known.

Differences in the internal energies of glass and crystal (Table 9) are again nearly identical to the enthalpy differences at 1 bar. The 
available data suggest, however, that effects of temperature and pressure on $\Delta \bar{H}$ are considerably greater than noted above for the crystals (White, 1919; Vergano et al., 1967; Chao and BelL, 1969; Bell and Roseвоом, 1969, p. 159), but much experimental work is still needed to determine the effects of annealing and densification on the enthalpies, heat capacities, compressibilities, and thermal expansions of liquids in this system.

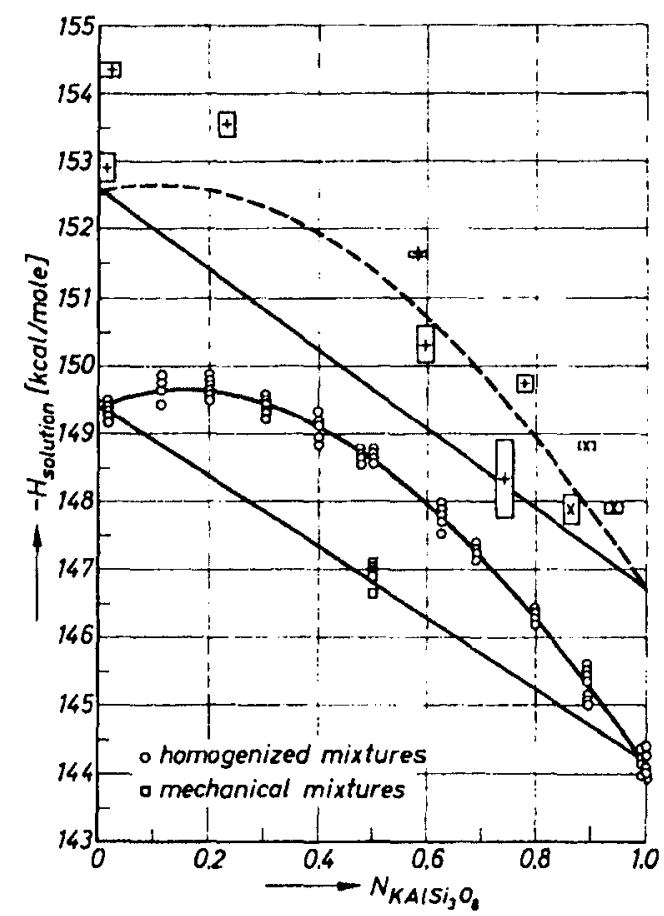

Fig. 5. Heats of solution of natural and synthetic alkali feldspar crystalline solutions in $20.1 \%$ hydrofluoric acid referred to $49.7^{\circ} \mathrm{C}$. Solid curve represents equation (7). Dashed curve refers to sanidine solutions, calculated from data for end members in Table $\theta$ and enthalpy of mixing parameters at 1 bar obtained from (2a) and (2b) of Waldbaum and Thompson (1969). Straight lines refer to mechanical mixtures of the end members calculated from (7) by setting the last two coefficients equal to zero, and from the high albite and sanidine values. Rectangles represent data of KraCEK and NEUvonEN (1952) corrected to $49.7^{\circ} \mathrm{C}$ (width of bars corresponds to \pm 1.5 mole- $\%$ ); $\times$ denotes samples containing low-albite lamellae, and are therefore not strictly comparable to sanidine solutions 


\section{Low-albite-microcline crystalline solntions}

Calorimetric data for the microcline crystalline solutions (Table 7) are plotted as open circles in Fig. 5 . It is clear that the magnitude of the heat of solution does not vary linearly with the $K /(\mathrm{K}+\mathrm{Na})$ ratio of the crystal, as KRACEK and Neuvonex's data in Fig. 5 might be interpreted. Least-squares fits to the data in Table 7 yield the following quadratic and cubic formulations (in $\mathrm{kcal} / \mathrm{mole}$ ):

$\bar{H}_{\mathrm{sol}}=-149.527( \pm .011)+5.414( \pm .012) N_{2}-7.075( \pm .044) N_{1} N_{2}$

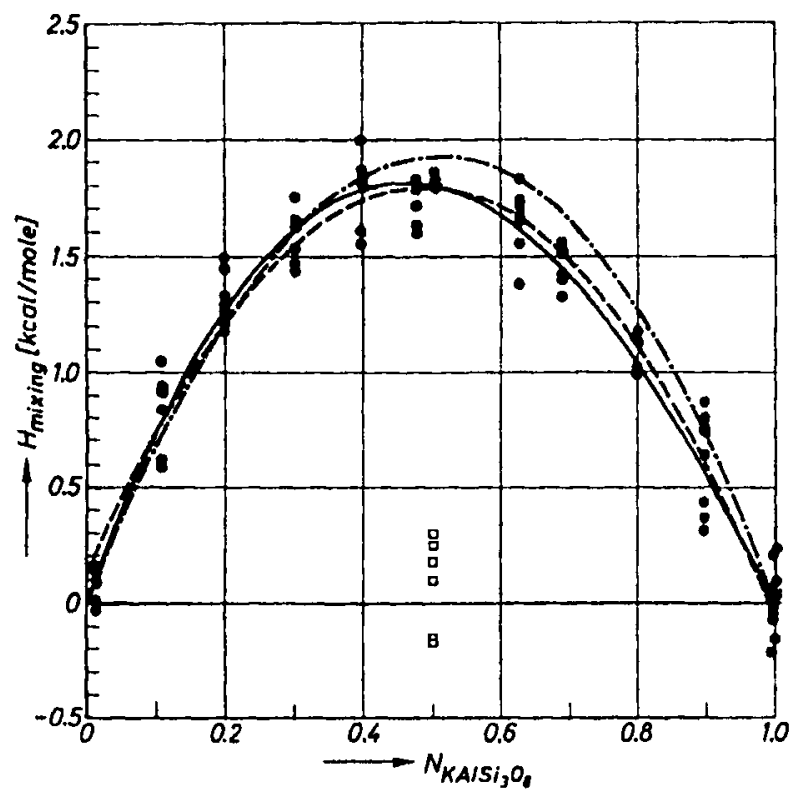

Fig. 6. Enthalpies of mixing of microcline crystalline solutions at 1 bar. Solid curve represents (7) or (8) as in Fig. 5. Circles (solutions) and squares (mixture) represent difference between observed values in Tables 7 and 8 and the line of mechanical mixtures for microclines in Fig. 5. Dashed curve refers to the difference between quadratic equation (5) and the same line of mechanical mixtures. Dot-dash curve is calculated from enthalpy parameters based on 2-phase data (11)

and

$$
\begin{aligned}
\vec{H}_{\mathrm{Bol}} & =-149.408( \pm .013)+5.230( \pm .017) N_{2} \\
& -5.928( \pm .085) N_{1} N_{2}{ }^{2}-8.457( \pm .099) N_{2} N_{1}{ }^{2}
\end{aligned}
$$

The standard deviation of (6) is $\pm 0.15 \mathrm{kcal}$, and is $\pm 0.13 \mathrm{kcal}$ for (7). The residuals were not improved by going to higher-order fits, although 
more closely spaced data might eventually warrant it. Equation (7) is plotted in Fig. 5.

The heat of solution of an equimolar mechanical mixture of $K$ and $\mathrm{Na}$ exchange derivatives of Amelia microcline was also determined in this study (Table 8). The data fall close to the hypothetical line representing the heats of solution of mechanical mixtures as calculated from (7) and shown in Figs. 5 and 6.

The heats of solution of the pure $\mathrm{K}$ and Na derivatives of Amelia microcline (amazonite) calculated from (7) are less negative than the results for Amelia albite and its $K$ derivative (6452) in Table 9 by about $550 \mathrm{cal} / \mathrm{mole}$. It is possible that some of this difference can be attributed to the rubidium or lead content of 6427 or 6444 (Tables 2 and 3). Judging from the poorer overall quality of the x-ray patterns of the microcline derivatives (WALDBAUM, 1966, Figs. 2-5), the differences in heats of solution may also be due to structural defects at grain boundaries within the perthite or, less likely, due to twinning.

\section{Excess mixing properties of microcline and other simple $\mathrm{Na}-\mathrm{K}$ crystalline solutions}

The heat of solution data of the microcline crystalline solutions yield from (7) a simple two-parameter Margules formulation (TrompsoN, 1967) for the excess enthalpy of mixing, $\widetilde{H}_{\text {ex }}$, at 1 atm:

$$
\vec{H}_{\text {ex [1 atm] }}=5928 N_{1} N_{2}^{2}+8457 N_{2} N_{1}^{2} \mathrm{cal} / \text { mole } .
$$

Equation (8) is plotted as a solid curve in Fig.6. The dashed curve in Fig. 6 is the difference between the quadratic formulation (6) and the line of mechanical mixtures computed from (7). The observed data shown in Fig. 6 are also referred to the same line of mixtures, and it is evident that the cubic equation (7) is a more precise fit to the data, particularly for $\mathrm{Na}$-rich compositions.

The volume data obtained at $25^{\circ} \mathrm{C}$ and 1 atm yield, from (1):

$$
V_{\text {ex }}=0.1101 N_{1} N_{2^{2}}+0.1101 N_{2} N_{1}^{2} \mathrm{cal} / \text { bar-mole }
$$

indicating positive volumes of mixing over the entire composition range. The values of the Margules parameters are similar in magnitude to those of sanidine crystalline solutions (WALDBAUM and THOMrPon, 1968).

Subtracting $P V_{\text {ex }}$ from (8) as above gives the following relation for the excess internal energy of $\mathrm{K}-\mathrm{Na}$ mixing (at zero pressure):

$$
\bar{E}_{\text {ex }}=5928 N_{1} N_{2}^{2}+8457 N_{2} N_{1}^{2} \mathrm{cal} / \mathrm{mole} \text {. }
$$


The Margules parameters $W_{E 1}$ and $W_{E 2}$ are identical with the enthalpy parameters in $(8)$ to the nearest calorie owing to the small $P \bar{V}_{\text {ex }}$ (=P $\bar{V}_{\text {mix }}$ ) contribution between $1 \mathrm{~atm}$ and zero pressure. It will be noted that the excess enthalpy, volume, and internal energy parameters obtained here are from direct physical measurements on bulk

Table 10

Internal energies of $\mathrm{Na}-\mathrm{K}$ mixing of some crystalline silicates and halides

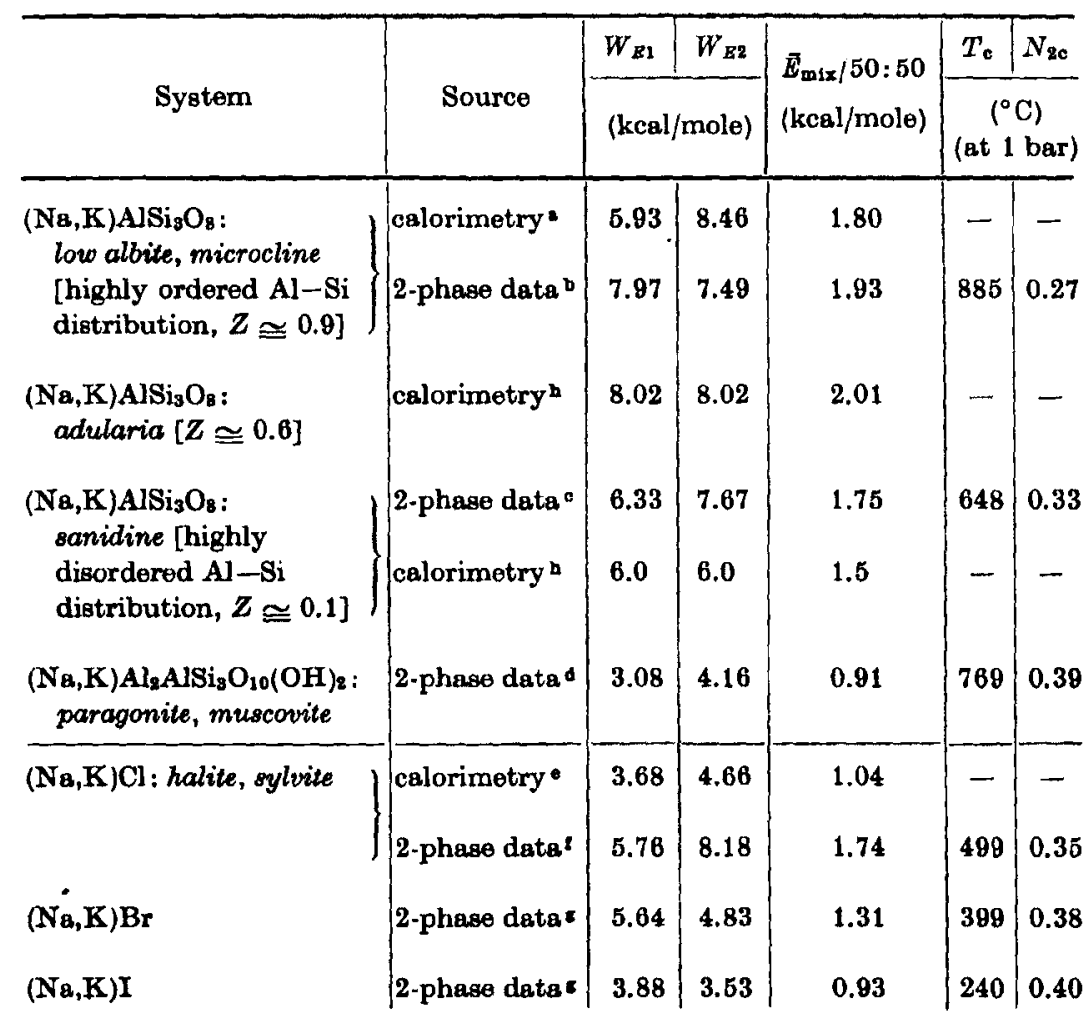

- This study.

- Bachunsia and Mürnegr (1971, Table 9).

c Thompron and Wandoaum (1969a).

d Eugsimer, Albee, Bence, Thompson and Walpbaum (1972).

- Calculations based on data of Tichelanar (1956).

s Thompgon and WAIDBaUM (1969 b), calculations baged on data of BARRETT and WALuACE (1954).

- Calculations based on data of Chang (1964).

- Based on preliminary resulte (WaLdBaUM, unpublished data). 
phases, and hence it is not possible to separate the effects of long-range and short-range ordering of the alkali atoms or of tetrahedral cations on these properties.

The internal energy of mixing of an equimolar microcline solution calculated from $(10)$ is given in Table 10. For the same composition, $P \bar{V}_{\text {ex }}$ at $10 \mathrm{kbar}$ is $1101 / 4=225 \mathrm{cal} / \mathrm{mole}$. Although $225 \mathrm{cal}$ is relatively small compared with $\vec{H}_{\text {ex }}$ (and almost within the uncertainty in the data), it will have a substantial effect on the calculated phase relations at 10 kbar (compare Figs. 1 and 2 of WALDBaUM and THOMPSoN, 1969).

Since the work of Eastman and Mrrner (1933), it has generally been accepted that the excess entropy of mixing of crystalline solutions is near zero, and if not zero, more likely negative (due to short-range ordering). If the excess entropy of $\mathrm{Na}-\mathrm{K}$ mixing of microcline solutions is assumed to be zero, we calculate from (8) a critical temperature, $T_{\mathrm{c}}$, of $1649^{\circ} \mathrm{C}$ and a critical composition of 39 mole- $\% \mathrm{KAlSi}_{9} \mathrm{O}_{8}$ $\left(N_{2 \mathrm{c}}=0.39\right)$ at $1 \mathrm{~atm}$. However, this is not in agreement with the critical temperatures suggested by the alkali homogenization results of Orville (1967), the two independent studies of BACHINsKI and MÜLLER (1971), and this study, all of which indicate that $T_{\mathrm{c}}$ for microcline solutions is less than $950^{\circ} \mathrm{C}$ at $1 \mathrm{~atm}$. (A critical temperature higher than $1649^{\circ} \mathrm{C}$ results if the excess entropy is assumed to be negative.) To obtain a critical temperature that agrees with the direct observations on the two-phase region, it is necessary to assume relatively large, positive excess-entropy parameters.

A simple polythermal Margules formulation of BACHINski's twophase data.(method I of ThOMPson and WaIDBa UM, 1969a) does in fact yield positive values of $W_{S 1}$ and $W_{S 2}$ on the order of $+4 \mathrm{cal} / \mathrm{deg}$. mole, and an excess entropy of $+1 \mathrm{cal} / \mathrm{deg}$-mole at the $1: 1$ composition. The sign of this result implies that the excess entropy of homogeneous microcline crystalline solutions is predominantly vibrational (Trompson and WaLdBatum, $1969 \mathrm{~b}$, p. 685). Phase-equilibrium data alone, however, do not permit one to determine how the total excess entropy is partitioned between short-range ordering (clustering) and excess vibrational entropy. Heat capacity data for the crystalline solutions are needed to separate these effects.

The excess enthalpy of mixing also obtained from the two-phase data is given by

$$
\bar{H}_{\text {ex }}=7973( \pm 990) N_{1} N_{2}^{2}+7491( \pm 380) N_{2} N_{1}^{2} \text { cal } / \text { mole }
$$


which is in good agreement with that obtained by solution calorimetry (see Table 10 and dot-dash curve in Fig. 6).

Table 10 also compares mixing properties of some other $\mathrm{Na}-\mathrm{K}$ crystalline solutions: sanidines, micas, and halides. The similarities in the mixing properties and critical compositions would seem to be unusual for phases having such widely different structures, chemical compositions, and other physical properties. Although any conclusions based on Table 10 must be regarded as tentative, it appears that atoms or structural groups other than $\mathrm{K}$ and $\mathrm{Na}$ exert relatively little influence on the mixing properties of simple (one alkali site) K-Na crystalline solutions.

\section{Acknowledgments}

The authors wish to thank Professor James B. Thompson, JR. of Harvard University for his continued advice and encouragement throughout this investigation; Dr. Herbert R. Shaw, U. S. Geological Survey and Professor Prurp M. Orville, Yale Univ., for their suggestions on preparing large quantities of alkali feldspars for calorimetry; and Dr. Mrriam Kastiner, Harvard for obtaining the electronmicroprobe data. This investigation benefited from the advice and cooperation of many others, especially JERRY L. EDwARDs, George Washington Univ.; Professors Charles W. Burnham, Clurford Fronder, Cornelus Kretn, Harvard; Drs. Eugene C. Robertson, and David B. Stewart, U.S.G.S.; Professors Wrutam C. Luth and Clark C. Stephenson, M.I.T.; William W. Atkinson and Goy L. Hovis, Harvard; Dr. Jon L. Holm, Univ. Chicago; Sraron W. BAChIngki, Yale; and Warrea D. BaltzLeY of the Piedmont Mining Co., Amelia, Va.; Professor Josepr V. Suttr, Chicago; Drs. E-AN ZeN and D.B.Stewart reviewed the manuscript. The Department of Geological Sciences and the Higgins Fund of Harvard University, and the U.S. Geological Survey supported the experimental work. Computer costs were supported in part by a grant from the International Business Machines Corporation (to the Massachusetts Institute of Technology Computing Center), National Science Foundation grant GP-2723 (to the Harvard Computing Center), and NSF grant GA-12869, Harvard. We thank Rodolpe RAspet, Wilussm H. Wilson, Raymond C. Werre, Harold J. Ames, Maurice L. Campot, and the late Arthur W. Ames for capable technical assistance in various aspects of this study. 


\section{Relerences}

S. W. BACHinski and G. MürLer (1971), Experimental determinations of the microcline-low-albite solvus. J. Petrology 12, 329-356.

C. R. Barber (1968), The International Practical Temperature Scale of 1968. Metrologia 5, 35-44.

W. T. Barrett and W. E. Watlace (1854), Studies of $\mathrm{NaCl}-\mathrm{KCl}$ solid solu. tions. I. Heats of formation, lattice spacings, densities, Schottky defects and mutual solubilities. J. Amer. Chem. Soc. 76, 366-369.

T. F. W. BARTH (1965), On the constitution of the alkali feldspars. Tschermaks min. petrogr. Mitt. 10, 14-33.

P. M. BErL, and E. H. Roseroom, JR. (1969), Melting relationshipa of jedeito and albite to 45 kilobars with comments on melting diagrams of binary systems at high pressures. Min. Soc. Amer. Spec. Pap. 2, 151-161.

C. W. Burnham (1962), Lattice constant refinement. Carnegie Inst. Wash. Yearb. 61, 132-135.

N. B. Chane (1964), Equilibres des systemes binaires d'halogénures de sodium et potassium à l'état solide. J. Chim. Physique 8, 1428-1433.

E. C. T. Chao and P. M. BeLL (1069), Annesling characteristics of dense feldspar glase. Carnegie Inst. Wash. Yearb. 67, 126-130.

A. G. Cols, J. O. Hutchens, R. A. Robre and J. W. Stout (1960), Apparatus and methods for low temperature heat capacity measurements. The heat capacity of standard benzoic acid. J. Amer. Chem. Soc. 82, 4807-4813.

J. Coorg, R. S. JessuP and K. VAN Nes (1056), Calibration of calorimeters for reactions in a bomb at constant volume. In: F. D. Rossnsr, od., Experimental thermochemistry, Vol. I, 27-58. Interscience, New York.

J. P. Covanun (1962), Solution calorinetry and silicate thernochemistry. In: H. A. SKINNER, od., Experimental thermochemistry, Vol. II, 293-320. Interscience, Now York.

G. Donnay and J. D. H. Donnay (1952), The symmetry change in the hightemperature alkali-feldepar series. Amer. J. Sci., Bowen Vol., 115-132.

T. B. DovarAs (1969), Conversion of existing calorimetrically determined properties to the basis of the Intarmational Practical Temperature Scale of 1868. J. Res. Nat. Bur. Standards 78 A, 451-470.

E. D. Eustaran and R. T. Muner (1933), The entropy of a crystalline solution of silver bromide and silver chloride in relation to the third law of thermo. dynamics. J. Chern. Physics 1, 444-456.

H. P. Eugster, A. L. Albee, A. E. Bence, J. B. Thompron, JR., and D. R. WaLdBaU⿴囗十 (1072), The two-phase region and excess mixing propertios of paragonite-muscovite crystalline solutions. J. Petrology 18, 147-179.

C. P. Frtzarmans and B. J. Krakeride (1970), A precision onthalpy of solution calorimeter for slow rates of solution. The enthalpy of vitreous silica in hydrofluoric acid. J. Chem. Therm. \&, 265-273.

J. R. Gold8mitg and F. LAves (1954), The microclino-8anidino stability relations. Geochim. Cosmochim. Acta 5, 1-19.

H. D. Grundy, W. L. Brown and W. S. Mackunze (1967), On the existence of monoclinic NaAlSis $\mathrm{O}_{3}$ at elevated temperatures. Min. Mag. 86, 83-88. 
S. R. GuNN (1864), Note concerning an electrical heater error in the rockingbomb solution calorimeters. Rept. UCRL-7992, Lawrence Radiation Lab., Los Angeles, Calif.

S. HAFNER und F. LAves (1957), Ordnung/Unordnung und Ultrarotabsorption. II. Variation der Lage und Inteneität einiger Absorptionen von Feldspäten. Zur Struktur von Orthoklas und Adular. Z. Kristallogr. 109, 204-225.

K. S. HeIER (1962), Trace elements in feldspars-a review. Norsk Geolog. Tidsskr. [Feldspar Vol.] 42, 415-454.

T. Hrabse and O.J. KLepPa (1968), The thermochemiatry of jadeite. Amer. Min. 68, 1281-1292.

J. L. HoLx and O. J. KLEPPA (1968), Thermodynamics of the disordering process in albite. Amer. Min. 58, 123-133.

G. L. Hovis, D. R. WALDBafm and J. B. Thompson, JR. (1970), Celorimetric studies of $\mathrm{Al}-\mathrm{Si}$ ordering and $\mathrm{Na}-\mathrm{K}$ mixing in monoclinic alkali feldspars. Gool. Soc. Amer. Abstracts with Programs 8, 682.

C. HunmeL und H. E. SchwIETe (1959), Thermochemische Untersuchungen im System $\mathrm{Na}_{2} \mathrm{O}-\mathrm{SiO}_{2}$. Teil I. Lö日ungskalorimetrische Untersuchungen von Bildungs- und Reaktionswärmon. Glastechn. Ber. 82, 327-335.

M. Kastaner (1969), Authigenic feldspars in carbonate rocks. Ph. D. Thegis, Harvard Univ., Cambridge, Mass.

M. KAstNer and D. R. WATDBAUM (1968), Authigenic albite from Rhodes. Amer. Min. 58, 1579-1602.

E. G. KnNo (1951), Heat of formation of crystalline calcium orthosilicate, tricalcium silicate and zinc orthosilicate. J. Amer. Chem. Soc. 78, 656658.

F. C. KRACEK and K. J. NEUVONEN (1952), Thermochemistry of plagioclese and alkali feldspars. Amer. J. Sci., Bowen Vol., 293-318.

F. Iaves (1960), Al/Si.Verteilungen, Phasen-Transformationen und Namen der Alkalifeldspäte. Z. Kristallogr. 113, 265-296.

F. LAVES und S. HAFNER (1956), Ordnung/Unordnung und Ultrarotabsorption. I. (Al,Si)-Verteilung in Feldspaten. Z. Kristallogr. 108, 52-63.

F. LAVEs and S. HArNen (1962), Infrared absorption effects, nuclear magnetic resonence and structure of feldspars. Norsk Geol. Tidsakr. [Feldspar Vol.] 48, $57-71$.

D. H. LnNDsLex (1866), Melting relation of $\mathrm{KAlSi}_{3} \mathrm{O}_{\mathrm{g}}$ : Effect of pressure up to 40 kilobars. Amer. Min. 51, $1793-1798$.

W. C. Luth and F. Quarol-Suña' (1970), An alkali feldspar serieg. Contrib. Min. Petrology 95, 25-40.

W. C. Lotr and O. F. TUTTL (1966), The alkali feldspar solvus in the system $\mathrm{Ne}_{2} \mathrm{O}-\mathrm{K}_{2} \mathrm{O}-\mathrm{Al}_{2} \mathrm{O}_{4}-\mathrm{SiO}_{2}-\mathrm{H}_{2} \mathrm{O}$. Amer. Min. 51, 1359-1373.

W. S. Mack Sci. $255,481-516$.

W. S. MACKENZIE and J. V. SmITH (1861), Experimental and geological evidence for the stability of alkali feldspars. Cursillos y Conferencias Inst. 'Lucas Mallade' Invest. Geol., Fasc. VIII, 63-69.

W. 8. MacKenzis and J. V. Surte (1962), Single crystal x-ray studies of cryptoand microperthites. Norak Geol. Tidsskr. [Feldspar Vol.] 42, 72-103.

2. Kristallogr. Bd. 134, 5/6 
D. MoKre and J. D. C. McConneII (1963), The kinetics of the low - high trans. formation in albite. I. Amelia albite under dry conditions. Min. Mag. 88, $581-588$

R. F. Martin (1969), The hydrothermal synthesis of low albite. Contrib. Min. Petrology 28, 323-339.

R. F. Martin and M. Lagache (1970), L'effet du remplacement du potasgium par le rubidiurn sur les paramètres de la maille de la sanidine et la leucito. Bull. Soc. franç. Min. Cristallogr. 83, 581-582.

C. H. MEYERs (1932), Coiled filament resistance thermometers. J. Res. Nat, Bur. Standards $8,807-813$.

S. A. Morse (1870), Alkali feldspars with water at $5 \mathrm{~kb}$ pressuro. J. Petrology $11,221-251$.

O. MüLxrat (1912), thber die Thermochemie der Kieselsäure und der Silikate. Z. anorg. Chem. 75, 198-240.

I. OfTEdax (1957), Heating experiments on amazonite. Min. Mag. 81, 417-418.

P. M. Onvilue (1963), Alkali ion exchange between vapor and feldepar phases. Amer. J. Sci. 261, 201-237.

P. M. OrvmLe (1867), Unit-cell parameters of the microcline-low albite and the sanidine-high albite series. Amer. Min. 52, 55-86; 58, 346-347.

W. PArRisir (1960), Results of the I. U. Cr. precision lattice parameter project. Acta Crystallogr. 18, 838-850.

I. PArsons (1968), An experimental study of ordering in sodium-rich feldspars. Min. Mag. 86, 1061-1077.

G. S. Plyusnin (1969), [On the color of amazonite]. Zap. Vses. Min. Obshch. 98, 3-17 [in Russian].

B. V. L. N. RAO (1959), Low temperature alkali feldspar series. Norsk Geolog Tidsskr. 89, 275-288.

R. A. RoBre (1965), Vacuum-jacketed hydrofluoric acid solution calorimeter. Rev. Sci. Instr. B6, 484-486.

F. D. Rossini (1956), General principles of modern thermochemistry. In : F. D. Rossins, ed., Experimental thermochemistry, Vol. I, 1-20. Interscience, New York.

F. D. Rossini and W. E. Drmina (1939), The essignment of uncertainties to the deta of chemistry and physics, with specific recommendations for thermochemistry. J. Wash. Acad. Sci. 29, 416-440.

W. A. Rotr und H. Trortzsch (1932), Bildungswärme von Metakalziumsilikat (Wollastonit) und Ferroorthosilikat (Fayalit). Archiv Eisenhattonwesen 6, 78-83.

J. Snzrankas (1968), Classical mineral occurrences, I. Geology and mineralogy of the Rutherford pegmatites, Amelia, Virginia. Amer. Min. 58, 373-405.

J. V. Smitr and R. C. Stengtrom (1965), Electron excited luminescence as a petrologic tool. J. Geol. 78, 627-635.

E. SPEncer (1937), The potash-soda feldspars. I. Therroal stability. Min. Mag. 24, $453-494$.

D. B. Stewhat and D, von Limbace (1967), Thermal expangion of low and high albito. Amer. Min. 52, 389-413. 
D. B. StewARt and P. H. Ribbe (1969), Structural explenation for variation in cell parameters of alkali feldspar with Al/Si ordering. Amer. J. Sci. 967 A [Schairer Vol.], 444-462.

H. F. Strmson (1961), International Practical Temperature Scale of 1948. Text revision of 1860 . J. Res. Nat. Bur. Standards [A] 65, 139-145.

J. W. STout (1968), Low-temperature calorimetry with isothermal shield and evaluated heat leak. In: J. P. McCúLoDar and D. W. Scotr, Experimental thermodynamics. Vol. I. Calorimetry of non-reacting Bystems. 215-261. Butterworths, London.

G. TAmmann (1903), Kristallioieren und Schmelzen. J. A. Barth, Leipzig.

W. H. TAYLOK (1934), The nature and properties of aluminosilicate framework structures. Proc. Roy. Soc. [London] [A] 145, 80-103.

J. B. Thompson, Jr. (1867), Thermodynamic properties of simple solutions. In: P. H. Abelson, od., Researches in geochemistry. II. 340-361. John Wiley and Sons, New York.

J. B. Trompson, Jr. (1968), Chemical reactions in crystals. Amer. Min. 64, $341-375$.

J. B. Trompson, JR. (1970), Chemical resctions in crystals: Corrections and clarification. Amer. Min. 55, 528-532.

J. B. Thompron, JR. and D. R. WALbbaum (1969a), Mixing properties of sandine crystalline solutions. III. Calculations based on two-phase data. Amor. Min. 54, 811-838.

J. B. Thompson, Jr. and D. R. WaldaAum (1969b), Analygis of the two-phage region halite-sylvite in the system $\mathrm{NaCl}-\mathrm{KCl}$. Geochim. Cosmochim. Acta 33, 671-690.

G. W. TrChelaAr (1956), Onderzoek over de mengkristallen van $\mathrm{KCl}$ en $\mathrm{NaCl}$. Proefschrift, Techn. Hogeschool, Delft.

D. R. Toroeson and T. G. Sarama (1948), A hydrofluoric acid solution calorimeter and the determination of the heats of formation of $\mathrm{Mg}_{2} \mathrm{SiO}_{4}, \mathrm{MgSiO}_{3}$, and $\mathrm{CaSiO}_{2}$. J. Amer. Chem. Soc. 70, 2156-2160.

O. F. Tutrte and N. L. BowEN (1950), High-temperature albite and contiguous feldspars. J. Gool. 58, 572-583.

P. J. Vergano, D. C. Hill and D. R. Uhlmann (1967), Thermal expansion of feldspar glasses. J. Amer. Ceram. Soc. 50, 60-60.

D. R. Wasdanum (1966), Calorimetric invegtigation of the alkali feldspars. Ph.D. thesis. Harvard Univ., Cambridge, Mass.

D. R. WALDBAUM (1868), High-temperature thermodynamic properties of alkali feldspars. Contrib. Min. Petrology 17, 71-77.

D. R. War.dBaUM (1969), Some observations on preparing glass compositions on the alkali feldepar join. Amer. J. Sci. 267, 1249-1253.

D. R. Wardoaum, Experimental data and numerical procedures from calorimetric investigation of alkali feldspars. (In prep.)

D. R. Waldbaum and R. A. Ronre (1970), An internal sample container for hydrofluoric acid solution calorimetry. J. Geol. 78, 736-741.

D. R. Wardanum and J. B. Thokrpon, JR. (1968), Mixing properties of sanidine crystalline solutions. II. Calculations besed on volume date. Amer. Min. 58, 2000-2017. 
D. R. Waldbaum and J. B. Thompon, Jr. (1969), Mixing properties of sanidine crystalline solutions. IV. Phase diagrams from equations of state. Amer. Min. 54, $1274-1298$.

W. P. White (1919), Silicate specific heats. Second series. Amer. J. Sci. 187, 1-43.

P. P. Williams and H. D. Megaw (1964), The crystal structures of low and high albites at $-180^{\circ} \mathrm{C}$. Acta Crystallogr. 17, 882-890.

A. G. Worthing and J. Gefrner (1943), Treatment of experimental data. John Wiley and Sons, New York.

T. L. Wright and D. B. Stewart (1968), X-ray and optical study of alkali feldspar. I. Determination of composition and structural state from refined unit cell parameters and $2 V$. Amer. Min. 63, 38-87.

J. Wyart et G. Sabatier (1956), Transformations mutuelles des feldspaths alcalins. Reproduction du microcline et de l'albite. Bull. Soc. franc. Min. Cristallogr. 79, 574-581. 